\title{
Economic Optimal Implementation of Virtual Power Plants in the German Power Market
}

\author{
Dodiek Ika Candra ${ }^{1, *}$, Kilian Hartmann ${ }^{2, *}$ and Michael Nelles ${ }^{1,3}$ \\ 1 Department of Waste \& Resource Management, Faculty of Agricultural and Environmental Science, \\ University of Rostock, 18059 Rostock, Germany; michael.nelles@uni-rostock.de \\ 2 Department of Engineering Science, Faculty of Engineering, Aschaffenburg University of Applied Sciences, \\ 63743 Aschaffenburg, Germany \\ 3 Deutsches Biomasseforschunsgzentrum gGmbH (DBFZ), the Centre for Biomass Research in Germany, \\ 04347 Leipzig, Germany \\ * Correspondence: dc050@uni-rostock.de (D.I.C.); kilian.hartmann@h-ab.de (K.H.); \\ Tel.: +62-6021-4206-933 (K.H.)
}

Received: 9 August 2018; Accepted: 5 September 2018; Published: 7 September 2018

check for updates

\begin{abstract}
The burden of excess energy from the high renewable energy sources (RES) share creates a significant reduction of residual load for the future, resulting in reduced market prices. The higher the share of stochastic RES, the more often the price will be $0 € / \mathrm{MWh}$. The power market needs new methods to solve these problems. The development of virtual power plants (VPPs) is aimed at solving techno-economic problems with an increasing share of RES in the power market. This study analyses a possible implementation of stochastic and deterministic RES in a VPP to generate secured power, which can be implemented in the European Power Exchange (EPEX)/European Energy Exchange (EEX) power market using existing market products. In this study, the optimal economic VPP configuration for an RES-based power plant is investigated and implemented into standard power market products. The results show that the optimal economic VPP configuration for different market products varies, depending on the energy availability and the marginal costs of the VPP components. The size of the VPP components is positively correlated to the components' share of the energy generated. It was also found that projecting or implementing VPPs in Germany at current market prices (EPEX/EEX prices) is not yet economically feasible for a small share of market products. However, the secured power can be marketed on the SPOT and in the futures market with higher and more stable prices compared with the status quo.
\end{abstract}

Keywords: VPP; marketing; configuration; energy transition; power market; EPEX; EEX; power market products

\section{Introduction}

One of Germany's energy transition plans involves increasing the share of renewable energy sources (RES) in total electricity consumption, in order to reduce fossil-fuel dependencies over a long term perspective. The RES share of gross electricity consumption in Germany in 2016 has reached about $31.7 \%$, from a targeted share of $35 \%$ in 2020, and $80 \%$ in 2050 [1,2]. In 2015, Germany had a total power generation of $651.8 \mathrm{TWh}$ (51.8 TWh were exported, and 30\% originated from RES [3]). Until the end of 2014, the RES share was dominated by wind (77.3\%), followed by solar photovoltaics (PV) energy (15.5\%) and others (7.2\%) [4]. The contributors of this high share of RES to the total amount of electricity generated are not only large-scale power generators, but also the owners of decentralized energy resources (DER) and small-scale RES-based power plants, such as solar PV from private owners [5]. 
The problem with this high share of stochastic RES in the total amount of electricity generated, and its simultaneous power generation, is the temporary surplus of power. This surplus leads to a drop of prices tending to $0 € / \mathrm{MWh}$ in a free market [6]. The higher the share of stochastic RES, the more often the price will be $0 € / M W h$. The power market needs new methods to solve these problems [7].

The development of virtual power plants (VPPs) aims to solve techno-economic problems regarding an increasing share of RES in the power market. The implementation of VPPs in the power market is a possibility to convert energy from stochastic power plants into secured energy by mixing it with small amounts of energy from deterministic power sources. This approach not only provides secured power [8-17], but also brings DER, including RES, to the power market, to become competitive, as compared with fossil-based energy generators [18,19]. The VPP is a part of the internet of energy (a scenario in energy transition) [20], and it is a mature technology that has already been implemented [21]. It has been shown that DER in a VPP gain more revenues than independent and non-market-oriented DER operations [22]. In the VPP, DER also have the flexibility to participate in many trading options in the power market, such as in the Day-Ahead and in the Intraday markets [23-25]. The studies from the literature $[9,26]$ show that implementing RES in a VPP could reduce RES costs in short-term power markets, thus increasing benefits of RES.

Previous studies such as the works of $[27,28]$ have explored the implementation of a VPP in the power market with different control schemes. Many of the studies also concern the stochastic and deterministic analysis for demand response, such as that by the authors of [29], which can help the VPP to cope uncertainties of RES. However, studies on optimal economic VPP configurations for RES-based power plants in the existing market products, especially in Germany's power market, are still missing.

This study analyses a possible implementation of stochastic and deterministic RES in a VPP to generate secured power, which can be implemented to the EEX/EPEX power market using existing market products. In this study, the optimal economic VPP configuration for an RES-based power plant is investigated and implemented into standard power market products. The investigation on the projection of the VPP with different market products presents the idea to provide secured market products from the high RES share.

To address the issue in this study, the following steps are conducted:

- Data collection of load schemes and market prices (EEX, EPEX) for several market products (base, peak, off-peak, etc.).

- Adaptation of load data to the market products.

- Design of adapted VPP configurations, including an optimization concept and an information communication technology (ICT) concept.

- Balance of generation and load in an energy management algorithm.

- Sensitivity analyses to adapt and test the VPP components on different market products.

- Calculation of the contribution margin of the VPP in the analyzed scenarios.

This paper is organized as follows: In Section 2, materials and methods of the study are presented. In the materials part, the load profile, market prices, market products and adapted load profile to the market products are described. In the methods part, the configuration of the VPP, energy management, sensitivity analysis, and calculation of the contribution margin of the economic results are described. In Section 3, the economic optimal VPP configuration at different market products and contribution margin of the analyzed scenario results are presented. In Section 4, the results are analyzed, followed by the conclusions drawn in Section 5 .

\section{Materials and Methods}

The VPP is yet to be defined, but has widely-accepted general concepts. With regards to previous studies [19,30-39], VPPs can be categorized into two main concepts: technical or commercial VPP. Technical VPPs (TVPPs) focus on technical operations and on the services of DER, whereas commercial VPPs (CVPPs) focus on TVPPs in markets operations. The technical operation functions include 
real-time and scheduled operations, aggregations, ancillary services, forecasting functions, and DER maintenance and submissions. Both TVPPs and CVPPs have the same VPP components, which consist of generation technology, energy storage, and information and communication technology (ICT). Moreover, the targets of VPPs, with controls as well as boundaries and forecasting functions, are added as a component of the VPP $[18,33,40]$. The targets of VPPs in this study can be explained as being market products from the VPP.

In this study, the VPP was built from the combination of a solar PV system, a battery system, and an adapted biogas power plant. The biogas power plant used in this research is adapted from the "Controlling of Gas Production in Biogas Plants (ReBi)" concept [41] as a flexible power generator based on demand-driven biogas operation principle. According to the literature [42], the VPP delivers secured power for different load demands. The VPP components are divided in two main systems, which are the hardware and intelligent systems (Figure 1). In the hardware system, all of the hardware components of the VPP were made up. These include an applications server, a database server, a web server, local controllers, a battery system, and a biogas power plant. The solar PV power plant is not depicted in Figure 1; because in this case, the generated energy from the PV was derived from the local operator as external data. In the intelligent system, the "brain" of the VPP is built. This includes optimization tools and visualization tools within a graphical user interface (GUI).

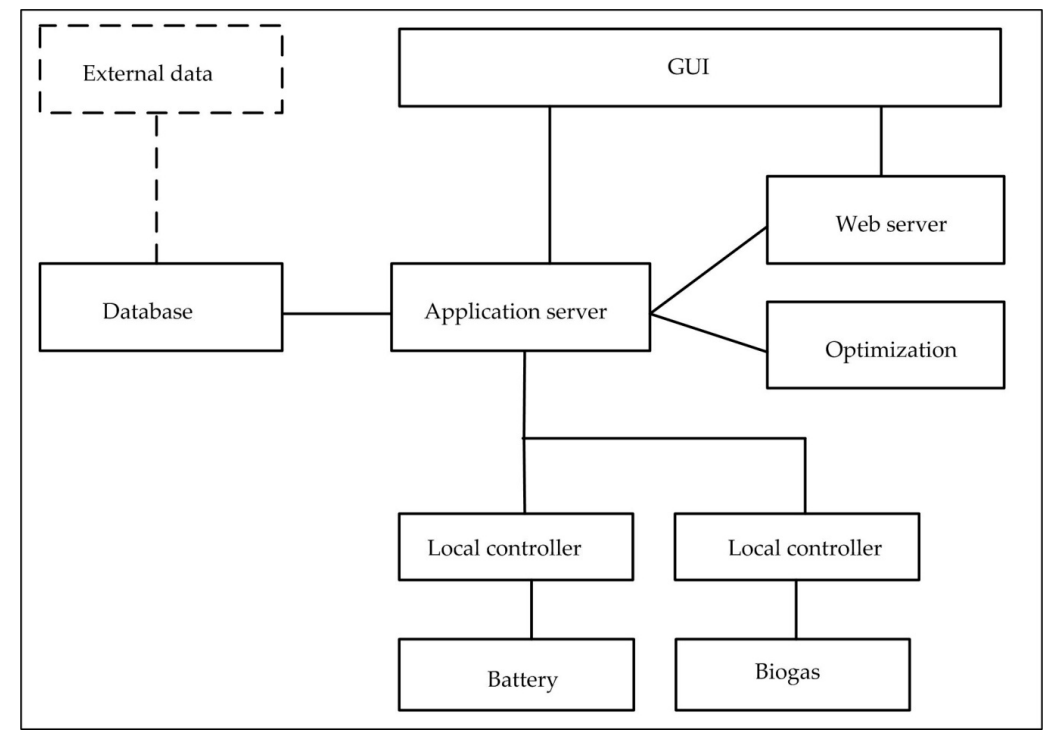

Figure 1. The virtual power plant (VPP) that was built during the study (adapted from the literature [42]).

\subsection{Material}

\subsubsection{Load Profile}

A load profile is an important component for estimating the power markets [43], and it gives information about the load fluctuations or the load durations in the power markets over a specific period of time. In this study, there were no specific parameters to be considered when selecting which load data would be used as the load profiles in the VPP. It was assumed that the VPP needed to be capable of addressing several kinds of load conditions. The load profiles that had the maximum load data for winter and for summer were then selected, and these were used as load profiles in the VPP. Later on, if the VPP was to be applied to other load data, the VPP's operator would be able to replace these load profile samples. The load data used in this study was derived from a local grid operator. There was a middle-size power plant in this grid, which influenced the expected standard load profile.

The following steps were conducted to generate a load profile from the load data for the VPP:

1. Visualizing the load data from a twelve-month load profile. The twelve-month load profile showed the load fluctuations over a year by representing a monthly range of load data. 
The twelve-month load profile of analyzed data (Figure 2) showed an overview of load conditions over the year 2015, which fluctuated between 8 MW and 110 MW.

\section{Load profile}

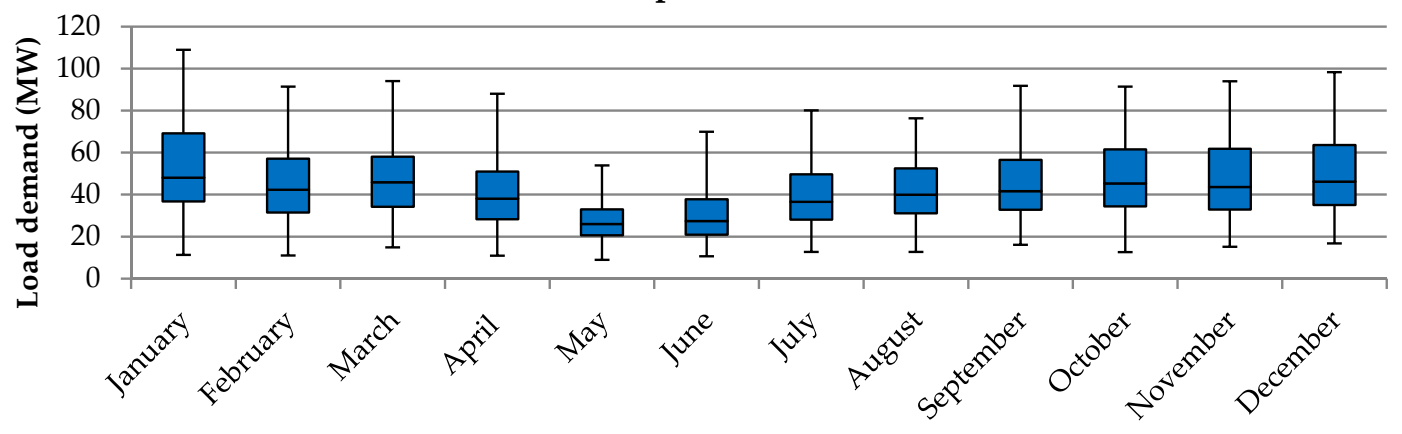

Figure 2. A twelve-month load profile of the study as a marketable figure.

2. Selecting a month. The maximum load range occurred during the winter and the summer periods. The load in January and the load in July from (Figure 2) were selected to represent the months that had the highest load levels in winter and summer, respectively. The four-week load data for these selected months were then visualized in an hourly-interval load profile (Figure 3).

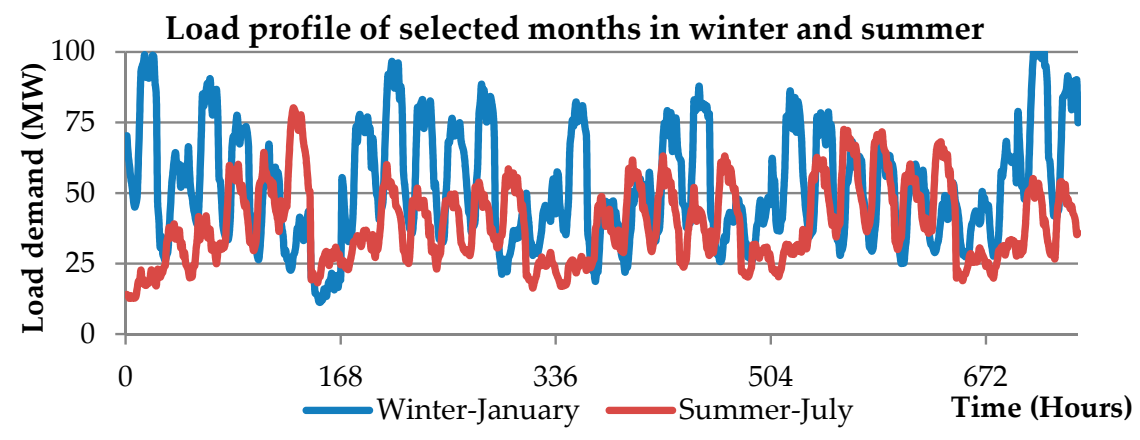

Figure 3. The load profile of selected months in winter and summer.

3. Selecting a week load data from the selected months. There were no specific criteria in this study for selecting the weekly load data from the selected months over summer and winter (Figure 3). The second week in July and the fourth week in January were randomly selected to be analyzed in this study (Figure 4). These weekly load data over summer and winter were then used in the Week Futures (WF) market.

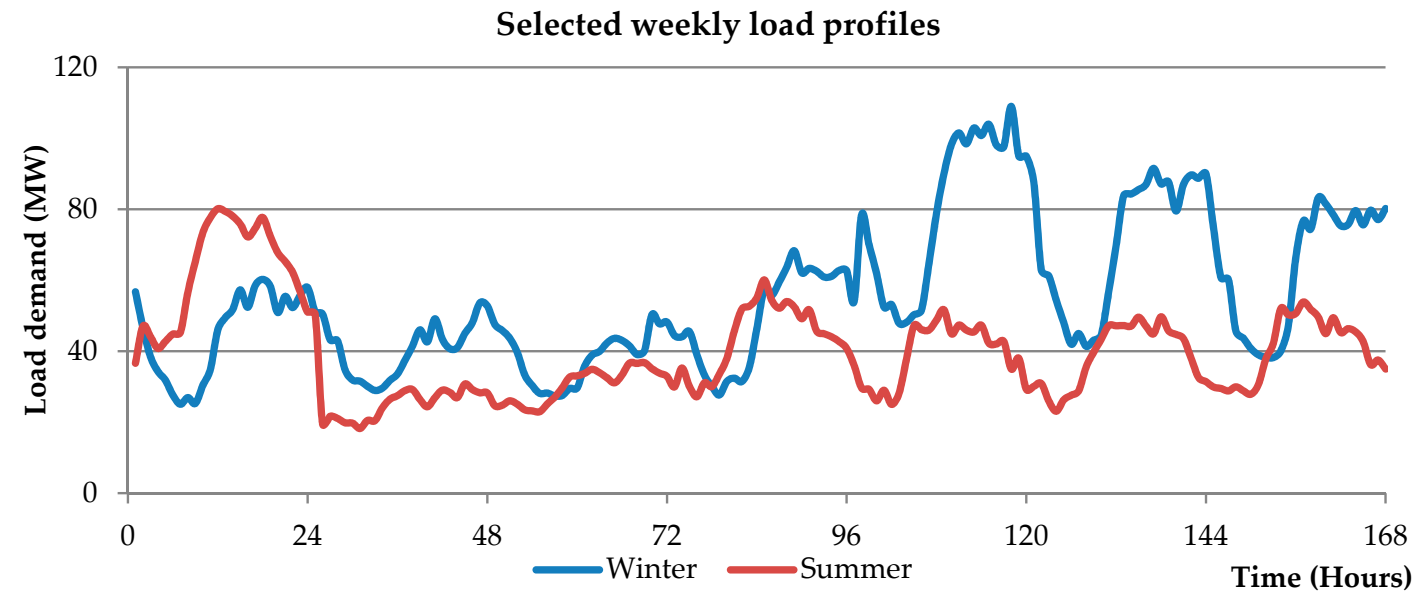

Figure 4. Selected weekly load profiles over summer and over winter for the study. 
4. Selecting two days from the weekly load profiles over summer and over winter as the samples of the load profiles in the Day-Ahead (DA) market in the SPOT market. As can be seen in the load profile in Figure 4, the highest loads during workdays in winter or in summer occurred on Monday, whereas the highest loads during weekends in winter or in summer occurred on Saturday. Thus, Monday and Saturday were selected to be used in the Day-Ahead market operation of the VPP (Figure 5).

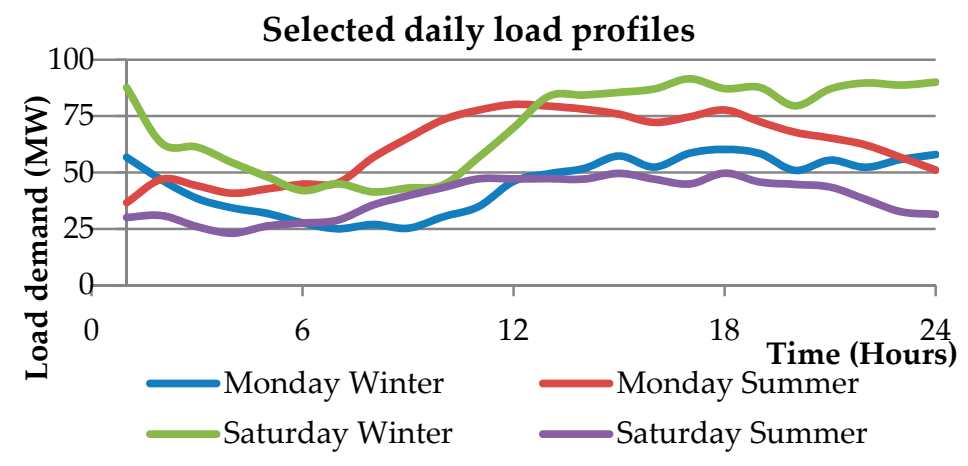

Figure 5. Selected daily load profiles over summer and over winter for the study.

\subsubsection{Market Prices Data and Market Products}

The market products of the VPP totaled $9 \times 68$ products for the Day-Ahead market, and $9 \times 4$ products for the Week Futures market (Appendix A, Table A1). In the Day-Ahead market, there were 17 types of market products (Table A2), based on the time for when the load was required, such as the peak load bid for a load between 08:00 and 20:00 [44]. In the Week Futures market, the market's products were the base load and peak load in summer or in winter. Nine (9) was a factor that represented the nine VPP configurations.

The market prices in the Day-Ahead or in the Week Futures market were constant over a specific time, for instance, the prices for peak load were constant from 08:00 to 20:00 [45]. Peak load demand occurred from Monday to Friday. A sample of the market prices for peak load in the Week Futures market can be seen in Figure 6. The complete market prices for both market types are provided by Table A3.

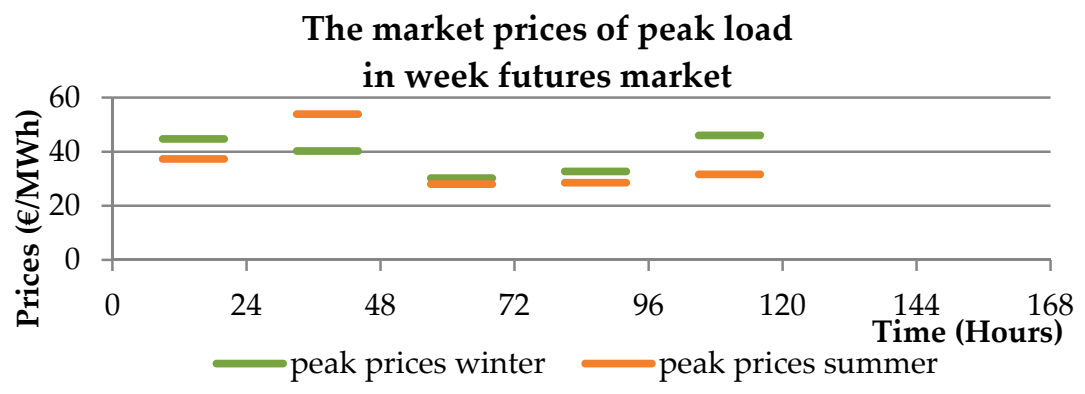

Figure 6. The sample of peak load prices over summer and over winter in the Week Futures market [45].

\subsubsection{Adaptation of Load Data to Market Products}

The load profiles from Figures 4 and 5 needed to be adapted to the market products. In this case, the volumes of the load demands in the Day-Ahead and the Week Futures markets were made constant for a specific period of time, referring to the literature [44]. For instance, the base load had a constant load over a $24 \mathrm{~h}$ period. The market prices and bid volumes of each of the market products were generated by a market mechanism where the demand and supply met. Equations (1) to (8) were considered based on the literature [46]. 
The bid volumes of the specific market products $\mathrm{x}$ in this study were then determined by Equation (1):

$$
\mathrm{BVOL}_{\mathrm{x}}=\sum_{\mathrm{k}=1}^{\mathrm{n}} \mathrm{c}_{\mathrm{x}, \mathrm{k}} \cdot\left(\frac{\sum_{\mathrm{k}=1}^{\mathrm{n}}\left(\mathrm{g}_{\mathrm{x}, \mathrm{k}} \cdot \operatorname{Pres}_{\mathrm{l}, \mathrm{k}}\right)}{\mathrm{s}_{\mathrm{x}}}\right)
$$

The base load calculation was made as in Equation (2):

$$
\text { Pbase }_{\mathrm{l}, \mathrm{k}}=\text { Pavg }_{\mathrm{l}, \mathrm{k}}-\text { Paravg }_{\mathrm{l}, \mathrm{k}}
$$

If a total load of the market category 1 was subtracted by the base load of the market category 1 , then there would be remaining load demands that were part of the total load, but not the part of the base load. In order to know whether there were any remaining load demands, Equation (3) was conducted:

$$
\text { Pres }_{1, \mathrm{k}}=\text { Ptot }_{1, \mathrm{k}}-\text { Pbase }_{1, \mathrm{k}}
$$

This remaining load signal was then calculated using Equations (4) and (5):

$$
\begin{aligned}
& \mathrm{g}_{\mathrm{x}, \mathrm{k}}=1\left(\text { when } \text { Pres }_{\mathrm{l}, \mathrm{k}}>0\right) \\
& \mathrm{g}_{\mathrm{x}, \mathrm{k}}=0\left(\text { when } \operatorname{Pres}_{\mathrm{l}, \mathrm{k}}<0\right)
\end{aligned}
$$

The number of remaining load demands' signals for the market product $\mathrm{x}$ were then calculated by Equation (6):

$$
\mathrm{s}_{\mathrm{x}}=\sum_{\mathrm{k}=1}^{\mathrm{n}} \mathrm{g}_{\mathrm{x}, \mathrm{k}}
$$

In order to simplify the process calculation and to reduce the processing time in the VPP in the Week Futures markets, Equation (7) for winter and Equation (8) for summer were then used to calculate the peak load in the Week Futures markets:

$$
\begin{aligned}
\text { Ppeakw }_{\mathrm{w}} & =2 . . \text { Paravg }_{5, \mathrm{k}} \\
\text { Ppeakw }_{\mathrm{su}} & =2 . . \text { Paravg }_{6, \mathrm{k}}
\end{aligned}
$$

The samples of these bid calculations for the Day-Ahead and Week Futures markets are depicted in Figures $7 \mathrm{a}-\mathrm{d}$ and $8 \mathrm{a}, \mathrm{b}$. The other bid type volumes are not depicted in the figures, but they are explained in Table A4.

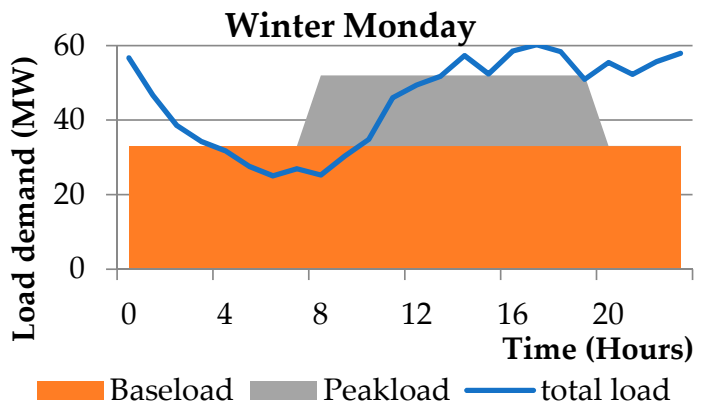

(a)

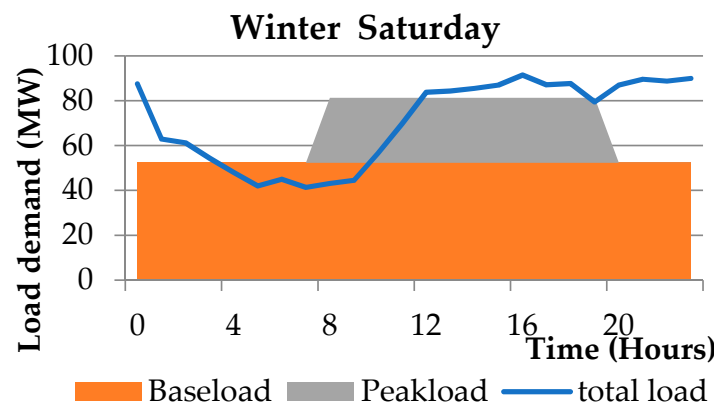

(b)

Figure 7. Cont. 


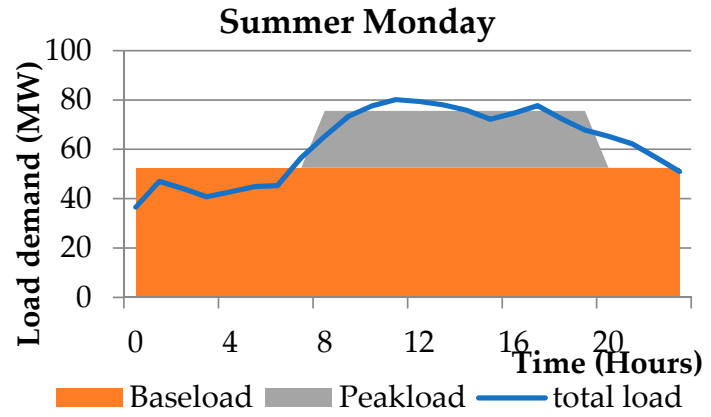

(c)

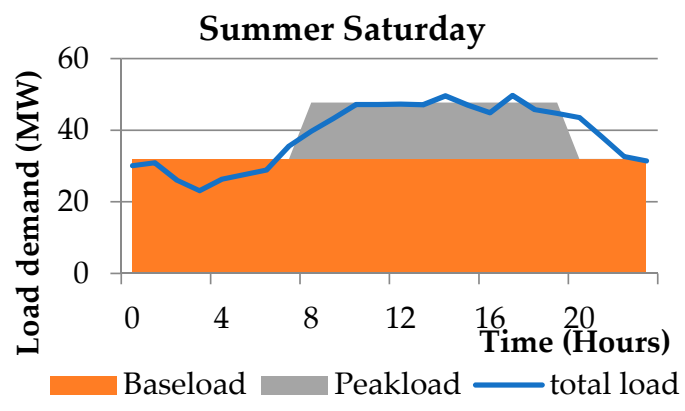

(d)

Figure 7. Adapted daily load profile of the base and peak loads for the samples of the Day-Ahead market on: (a) Winter Monday; (b) Winter Saturday; (c) Summer Monday; (d) Summer Saturday.

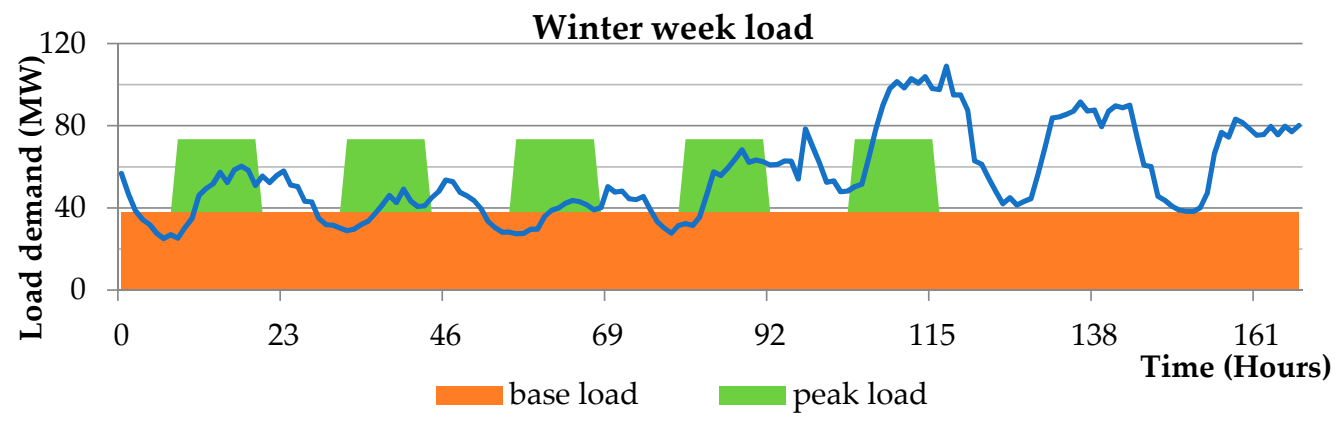

(a)

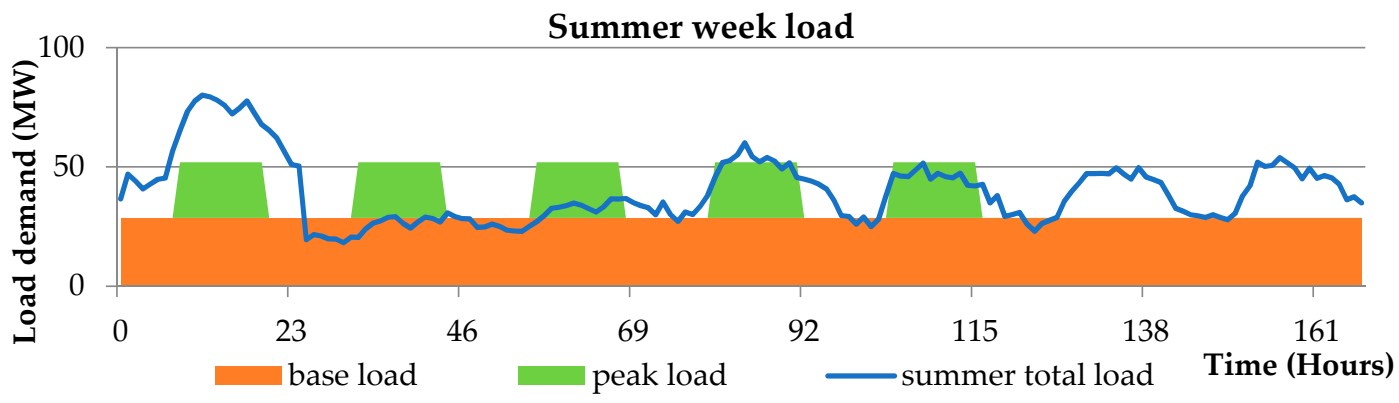

(b)

Figure 8. Adapted weekly load profiles of base and peak loads for the Week Futures market: (a) Winter Weekly; (b) Summer Weekly.

\subsection{Methods}

\subsubsection{The Configuration of the VPP}

The VPP was configured using two main methods: the optimization algorithm and the method for the ICT configuration of the VPP. The optimization concept was built as in the literature [42] to optimize the utilization of every single component in the VPP, such as a local controller in the biogas power plant. In the end, there would be a collection of entities in the VPP, which would collaborate with each other to meet common targets, that is, to address load demands. Energy and information exchanges are conducted by these entities in the exchange lines during the operation of the VPP (Figure 9).

The ICT components of the VPP were built as in the literature [47], based on the openness of the VPP components for future ICT developments. The ICT components of the VPP included the use of state-of-the-art advanced ICT security technology (virtual private network (VPN)), cloud computing, and exchange protocols (open platform communications (OPC), transmission control protocol-internet 
protocol (TCP-IP)). The main backbone of the ICT concepts for the VPP was the intensive use of open-source software based on community-based developments.

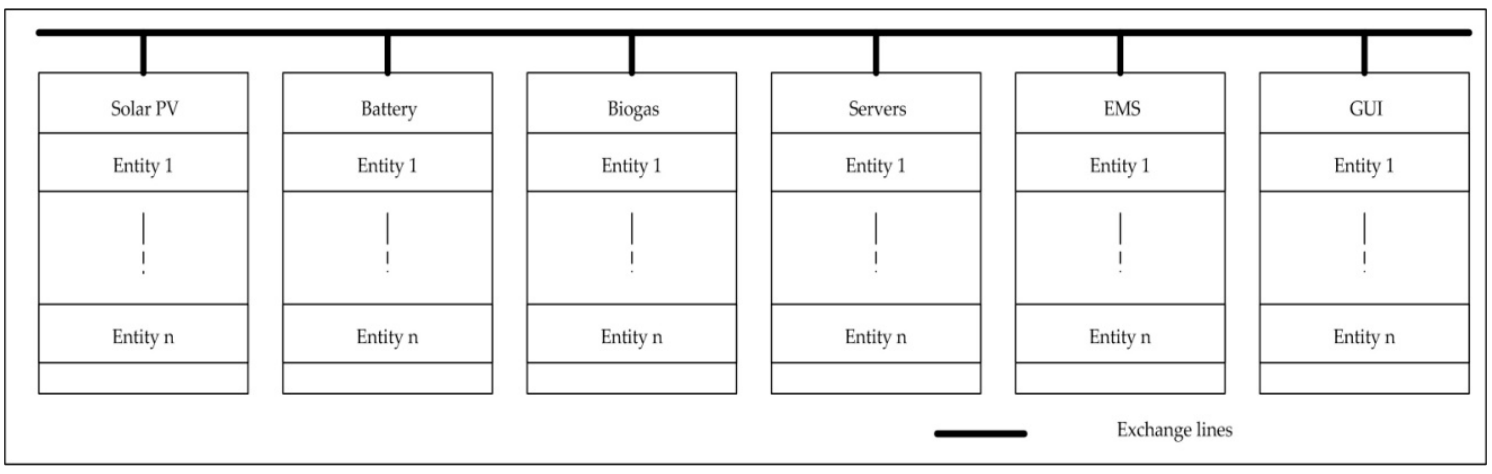

Figure 9. The configuration concept for the VPP (as given [42]).

\subsubsection{Energy Management}

The energy management of the VPP was based on an energy management plan as given in the literature [42], and an added component at the end of the energy exchange phase. The added component was a comparator that was intended to minimize the gap between the planned and the measured exchanged energies in the VPP. The merit order calculation was used as a strategy to aggregate the energy from the integrated energy sources (IES) [48]. The complete calculation of the IES cost and optimization was previously calculated in the literature [42]. To maintain security for the supply, with reduced generation costs in the VPP, the following considerations were taken into account for this VPP (Figure 10), as given in the literature [42]:

(a) The highest priority to meet the load demand was given to the power plants with the lowest marginal costs. Assuming that the sorted power plants, as based on marginal costs from the lowest to the highest, were the solar PV, the battery energy storage system (BESS), and the flexible biogas, the solar PV thus had the highest priority to meet the load. If the solar PV did not generate enough energy to meet the load, then the energy from the flexible biogas would be combined with the energy from the BESS (if applicable). If the solar PV generated more energy than the load, then the surplus energy from the solar PV would be stored into the BESS (in the case that state-of-charge (SOC) $<100 \%$, otherwise there would be nothing to do).

(b) As a result of biological constraints such as digestion time, the flexible biogas may need more time to aggregate its energy than the BESS. Thus, a BESS is still needed to support the flexible biogas in the operation of the VPP. If more/different intermittent RES were installed, that is, wind turbine power plants, the contribution of the BESS in the load could be minimized.

(c) The energy exchange was calculated at time $t$ 1, and then it was optimized again at time $t 2$. Time $t 1$ is the time when the aggregator or the operator makes the dispatch schedule for the Day-Ahead or Week Futures markets, such as on the day before the required delivery time for the energy. Time $\mathrm{t} 2$ is the minimum time required to compensate the gap between the scheduled and the measured exchanged energies. The balance of generation and load in an energy management system at time $\mathrm{t} 2$ is conducted by a comparator algorithm. Future investigation of time $\mathrm{t} 2$ should be conducted in practical implementation. In this study, $\mathrm{t} 2$ was determined to be about $2 \mathrm{~ms}$ with reference to the measured exchange rate in the literature [47].

In contrast to previous studies [49-52], the priority of the VPP implementation in this study was to provide secure power supply. It was assumed that all of the power plants of the VPP were participants in the energy market. However, the mechanism for selling surplus energy to the grid in this study was not economically considered, but it was instead considered as an energy surplus. 


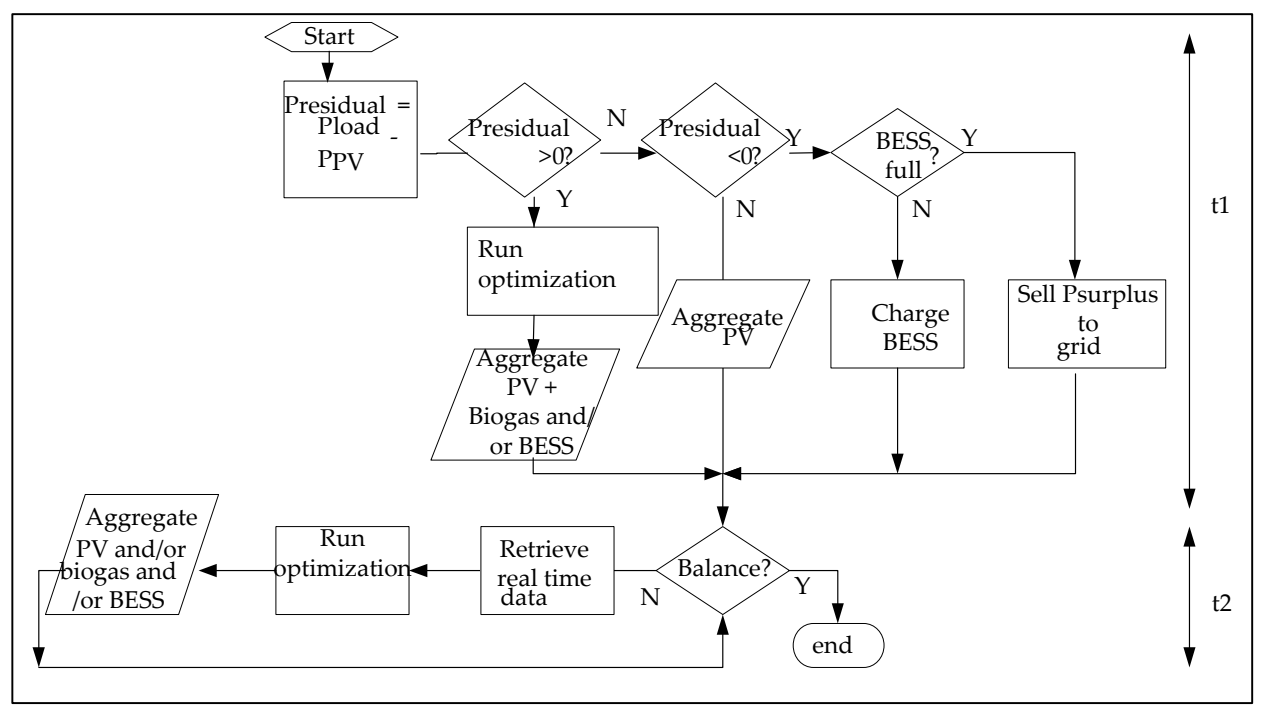

Figure 10. The energy management system (EMS) algorithm of VPP (as in the literature [42]) with a comparator algorithm.

\subsubsection{Sensitivity Analyses}

A sensitivity analysis was conducted by adoption and testing of the VPP components from different market products. The previous composition of the solar PV, the BESS, and the flexible biogas (Table 1, refer to Table 2 configuration 1) was scaled up and it was compared with other compositions such that at the end, there were nine configurations that were used for sensitivity analyses (Table 2). It was assumed that marginal costs of PV were $0 € / \mathrm{kWh}$, the BESS marginal cost varied (depending on market prices associated with the scenario $+10 \%$ losses), and the biogas marginal cost was 15 cents $€ / \mathrm{kWh}$ based on calculation derived from previous studies [53-58]. The optimal economic VPP configuration for different market products was analyzed by evaluating the optimal economic contributions of the VPP components, based on these nine VPP configurations.

Table 1. Parameters of the case study for the operations of the Day-Ahead and Week Futures markets.

\begin{tabular}{cc}
\hline Indicators & Capacity \\
\hline Solar PV (MW) & 15 \\
Biogas (MW) & 15 or $25^{1}$ \\
Battery (MWh) & 7.5 \\
\hline 1 for
\end{tabular}

Table 2. The composition of solar PV, BESS, and flexible biogas (BIO) (PV/BESS/BIO) for sensitivity analysis.

\begin{tabular}{cc}
\hline Configuration & Composition of PV/BESS/BIO \\
\hline 1 & $1: 1: 1\left(15: 7.5: 15\right.$ or $\left.25^{1}\right)$ \\
2 & $1: 2: 1$ \\
3 & $1: 3: 1$ \\
4 & $2: 1: 1$ \\
5 & $2: 2: 1$ \\
6 & $2: 3: 1$ \\
7 & $3: 1: 1$ \\
8 & $3: 2: 1$ \\
9 & $3: 3: 1$ \\
\hline
\end{tabular}




\subsubsection{Calculation of the Contribution Margin of the Economic Results}

To calculate the profits or losses of the economic results from energy management of the VPP, the cost analysis was performed by adopting the method conducted by the authors of [59]. The marginal costs and the market prices were compared in order to reveal the contribution margin of the VPP. The analysis based on marginal cost was aligned with one of the core features that was proposed by EPEX SPOT and EEX in further developments of the "erneubare energien gesetz" (EEG) [60]. The contribution margins were then calculated based on Equation (9) to 9 VPP configurations (Table 2):

$$
\mathrm{CM}_{1}=\mathrm{MP}_{1}-\mathrm{Copt}_{1}
$$

\section{Results}

When the 9 configurations of a total of 68 VPP products for the Day-Ahead market, and 4 products for the Week Futures market, were applied to energy management systems and Equation (9), the economic optimal VPP configuration and contribution margin of the different load schemes were quite different.

As an observation of VPP implementation in different load schemes, it was apparent that the share of the VPP's components in an optimal economic VPP configuration varied over weekday/weekend times, seasonal times, VPP component sizes, and the type of markets presented (Figure 11). As expected, the sizes of the VPP components had an influence on the share of power generated by the VPP components in economic and optimal VPP configurations. In the analyzed load schemes, VPP size enlargement had a positive correlation with the share of electricity from the VPP components that had minimum marginal costs. On the weekend, compared with the weekdays, the VPP required more energy from biogas. In the Week Futures market, the share of PV was not as high as it was in the Day-Ahead markets.

In the Day-Ahead market in winter, the VPP used more than $72 \%$ of its total energy from biogas in Configuration 1 (Figure 11a). When the sizes of PV and BESS were increased, the share of biogas in the VPP could be reduced to $53 \%$ in Configuration 9 on Monday. The increasing size of PV from Configuration 1 to 9 allowed the PV to increase its share in the energy generation of the VPP up to $41.5 \%$ on Monday in Configuration 9. The BESS has the smallest contribution to the total energy used in the VPP, with a maximum of $8 \%$ share on Monday in Configuration 3. Increasing the BESS size by Factor 3 caused an increase in the BESS share in the VPP's energy output of almost three-fold.

In the Day-Ahead market in summer, $60 \%$ of the total energy of the VPP was generated by PV. The maximum PV share in the VPP was about $80 \%$ in Configurations 7, 8, and 9 on Monday (Figure 11b). The rest of the share of the VPP was generated by biogas and BESS. The maximum biogas share in the VPP was a quarter of the total in Configuration 1 on Monday. This share decreased when the sizes of PV and BESS were increased. The use of BESS in the Day-Ahead market and in the Week Futures market in winter was relatively low (up to $10 \%$ in Configuration 3). Increasing the BESS size by a factor of 3 caused the BESS to take up an increased share of the VPP's power generation by almost the same factor.

In the Week Futures market, the optimal VPP configuration differed between winter and summer (Figure 11c). In winter (Configuration 1), almost 90\% of the energy used originated from biogas. The increasing share of PV reduced the share of biogas to $66.5 \%$, in Configurations 7 to 9 . The rest of the energy generated by the VPP came from PV. The share by BESS was not visible. In summer, the optimal VPP configuration was inverse compared to the winter scheme. The PV share was up to four-fifths of the total generated energy (in Configurations 7, 8, and 9), followed by biogas, which was up to a fifth of the total share. The contribution of BESS to the VPP in summer in Configuration 3 was less than $5 \%$.

Additionally, the trend of the VPP's average marginal costs for the different market products compared with the average market prices in the Day-Ahead and Week Futures markets can be seen in Figure 12. When the nine VPP configurations were applied to different market products (see Table A1) at Summer and Winter for Day-Ahead (on Monday and on Saturday) markets and Week Futures 
markets, the trends of the VPP's average marginal costs for both Day-Ahead and Week Futures markets were quite similar. The VPP's average marginal costs were reduced when the installed capacity of the VPP components increased. These costs were lower in summer than in winter. At some points such as in the Day-Ahead and Week Futures market in summer, the VPP's average marginal costs were lower than the average market prices.

\section{Average percent share of VPP's components in DA-market in Winter}

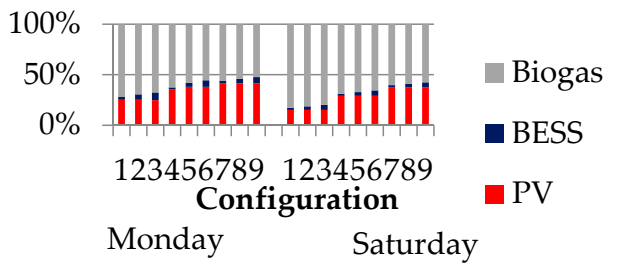

(a)

\section{Average percent share of VPP's components in DA-market in Summer}

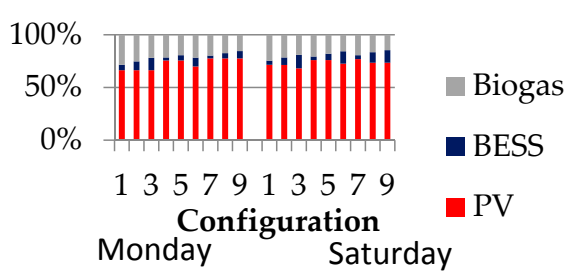

(b)

Average percent share of Solar PV, BESS, and Biogas in the VPP in Winter and in Summer in the Week Futures market

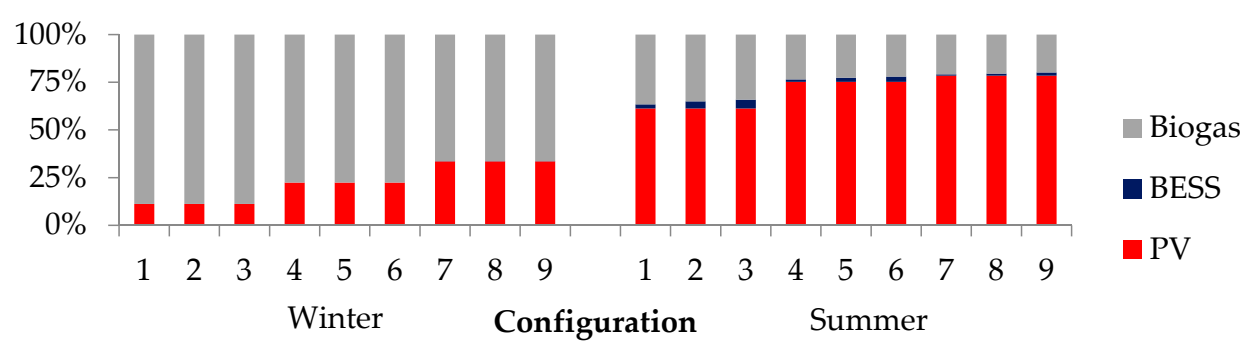

(c)

Figure 11. The share of PV, BESS, and biogas in the VPP for the different market products: (a) averages on Monday and Saturday in winter in the Day-Ahead (DA) market; (b) averages on Monday and Saturday in summer in the DA market; (c) in summer and winter in the Week Futures market.

The VPP's avg. marginal costs relative to the avg. market prices

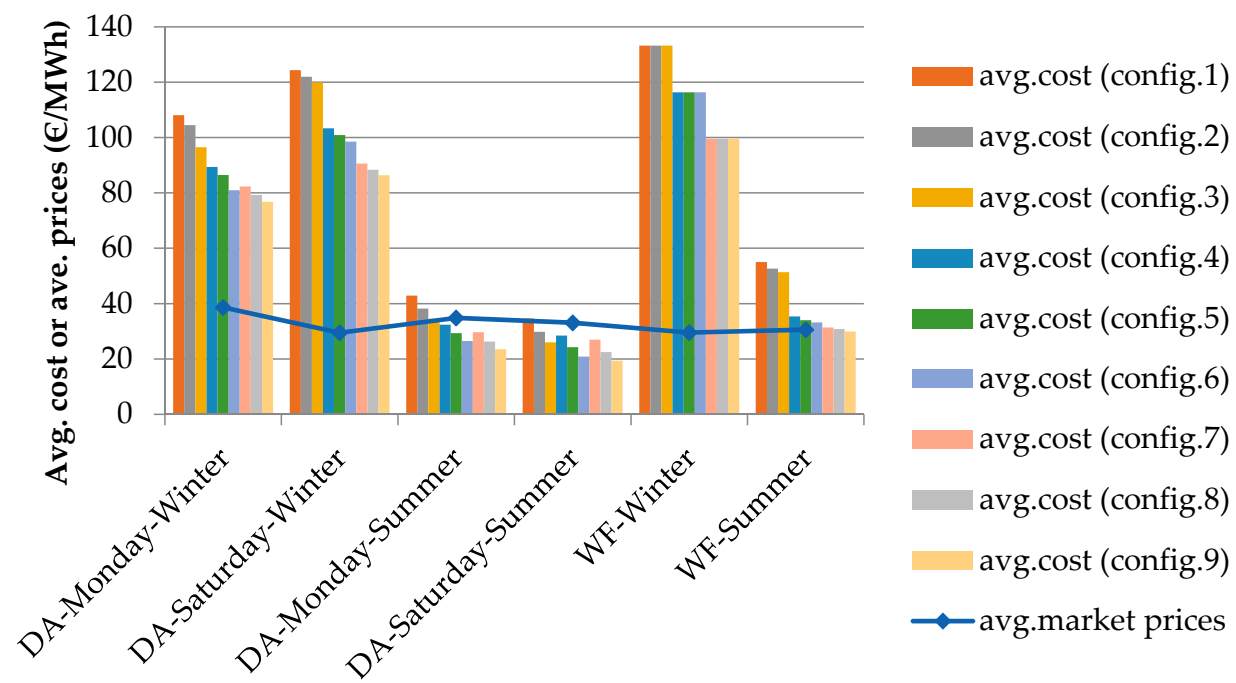

Figure 12. The average VPP's marginal costs as compared to the average market prices for different market products. 
The difference between the average market price and the VPP's average marginal cost was considered in terms of the average contribution margin (CM) of the VPP (Figure 13). The VPP earned a positive $\mathrm{CM}$ when it was implemented in the Day-Ahead market in summer. The maximum $\mathrm{CM}$ of the VPP was up to $14 € / \mathrm{MWh}$. For all other products and factors, such as during winter in the Day-Ahead and in the Week Futures markets, the CM was negative. The minimum CM in winter occurred in the Week Futures market, with an amount of up to $-105 € / \mathrm{MWh}$, followed by the Day-Ahead market on Saturday in winter (up to $-95 € / \mathrm{MWh}$ ), the Day-Ahead market on Monday in winter (up to $-70 € / \mathrm{MWh}$ ), and the Week Futures market in summer (up to $-25 € / \mathrm{MWh}$ ).

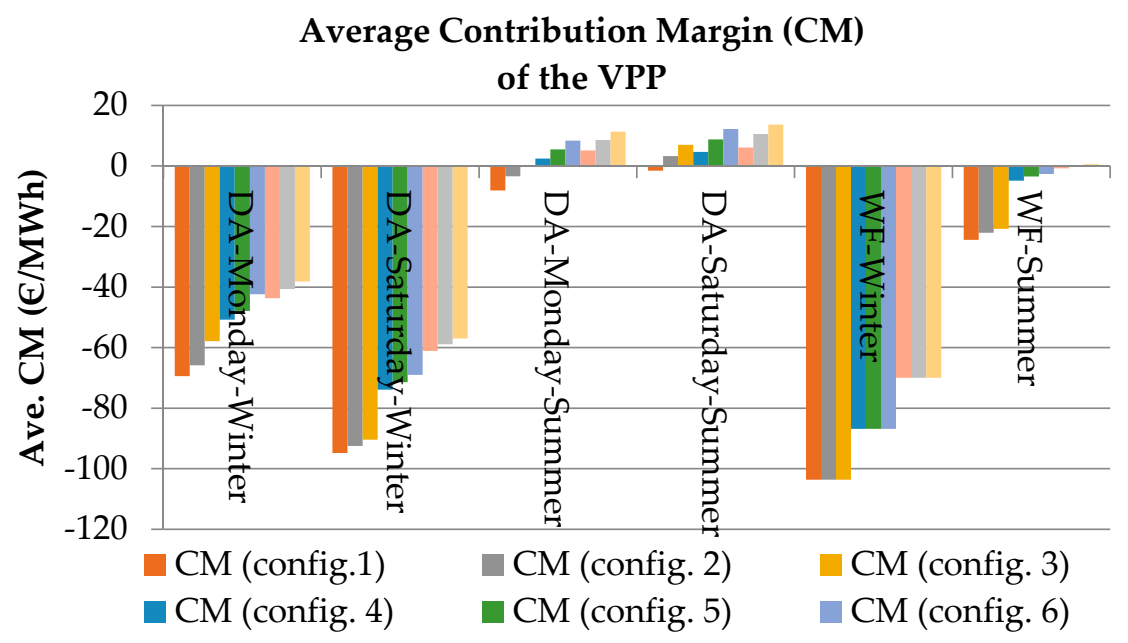

Figure 13. Average contribution margin of the VPP relative to the average market prices for different market products.

\section{Discussion}

The variations of economic optimal VPP configurations depend on the available energy and the VPP components' marginal costs. In summer, the solar PV contributed more energy to load demands than in winter. The share of the BESS to the load demand was limited by the amount of its stored energy. In this study, the BESS was only charged by the solar PV. When the energy from solar PV to charge the BESS was low, the stored energy in BESS was also relatively low. The other parameter that influenced the share of the BESS on the load demand was the remaining energy from the previous time-step discharged processes. The BESS will not have so much available energy when the energy from the PV is minimal and the discharged energy is maximal. The biogas had the highest possibility of having the highest share of the load demand because it had the highest power generation capability. Biogas could provide a more flexible and more reliable energy source compared with the other two VPP components. However, as the marginal cost of biogas was higher than the marginal costs of PV, there was still a possibility for reducing the VPP's average marginal costs by reducing the biogas share in addressing load demands. The introduction of another low marginal cost with intermittent RES, such as a wind turbine power plant, could minimize the average VPP's marginal cost.

The economic optimization of the VPP components shows that as much energy as possible should be generated by intermediate power plants, as long as the security of power supply is not harmed. In some instances, comparatively large shares of variable capacities (e.g., biogas) are necessary to secure the power supply, but in this case, the share of energy from intermediate resources is still quite large.

In this study, only intermediate power from PV systems was regarded. If wind power systems were to be additionally taken into account, higher shares of intermediate RES would be the result. The simultaneity effect would be smoothed. As a result, secured power from VPP based on RES could be offered with a higher energy share of cheap, intermediate RES, leading to lower generation costs. 
The results (Figure 12) revealed that the current market prices (EPEX and EEX prices) were lower than the VPP's average marginal costs for most market types and products. One of the reasons was the comparatively low price for electricity in the EEX and EPEX market. This was caused by offers from relatively low-cost energy that was generated from non-renewable energy sources, as well as a surplus of power supply in the market, which reduced the price.

As configuration 9 integrates the most power from PV with marginal costs of $0 € / M W h$, it could be preferably selected for VPP applications. This result could be transferred to other capacities with a marginal cost value of zero, as wind or run-of-river power stations. However, the energy surplus is one of the questions that the VPP operator should answer. Will the energy surplus be sold, or will it be throttled? Should more or less energy surplus be generated? In this study, the main consideration for determining IES size is a reduction of energy surplus, which is assumed to be related to low energy losses. On the other hand, it is also possible to generate surplus energy, if this energy surplus can be considered as additional revenue for the VPP. There must be further analyses made in order to reveal the actual prices of surplus energy. On the other hand, power from the VPP was generated at marginal costs of 20-80 €/MWh (summer-winter, best configuration), which were comparatively low prices for secured power from RES, but too much for an economically successful participation of the VPP in the EPEX market. Only when the share of energy from PV from the total power generated exceeded a certain level—such as in the Day-Ahead market in summer-would the VPP's marginal costs be lower than the market prices. From the results section, it can be seen that the solar-biogas-battery VPP is able to provide secured power at all times of the year. This secured power can be marketed on the SPOT, and in the Futures market at current prices. Especially in summer, the resulting contribution margin of power from the VPP is positive or close to the break-even point.

As a result, the implementation of a VPP to answer standardized load schemes of market products (base, peak, SPOT products) changes the fluctuating feed-in from RES into a secured and predictable power supply. This will lead to more stable prices in the energy market, and less grid control.

Moreover, economic optimization is based on the maximization of the contribution margin; this is in accordance with the standard marketing of electric power in SPOT and future exchanges. The results show that the contribution margin (Figure 13) is comparable to the contribution margin of gas power plants in the EPEX market. Regarding a cut in oversupply of power in the close future, both types of power plants could become economically successful (again).

Finally, the following can be concluded from the analyzed data:

- The energy availability and the marginal costs of the VPP's components influence decisions on economic optimal VPP configurations for different market products. In this study, it was found that biogas, as a flexible energy resource, followed by solar PV and BESS in the VPP, takes up most of the time in covering load demand as compared with other dependent RES. With the help of an energy management algorithm, the configuration of RES in the VPP will change automatically to their economic optimal compositions.

- Additionally, the size of the VPP components was positively correlated to the components' share of the energy generated. For an economic optimization, it is thus necessary to maximize the share of cheap stochastic power sources and reduce the amount of expensive deterministic sources. Such can be done by limiting the power of wind and solar power plants in relation to the deterministic sources, so that less power peaks have to be integrated in the power band.

- The organization of RES in VPPs leads to the generation of secured power generation instead of fluctuating power generation. This secured power could be sold in the Futures market at higher and more stable prices compared with the status quo.

\section{Conclusions}

The paper presents the capability of VPPs to provide secured power market products based on EEX/EPEX standards. A local grid load profile was used to be answered with these market products. Analyses-including sensitivity analyses-of several VPP configurations and the resulting costs were 
investigated to reveal the contribution margin of the VPP for different market types (Day-Ahead and Week Futures).

There were two main points found during this study, which are as follows:

- for all 9 VPP-configurations in the Day-Ahead and futures market, there were different figures in the economic optimal VPP configuration and contribution margin of the different load schemes. It was not only determined how the VPP manages its resources, but also how the other factors influenced the VPP's behavior. For instance, the economic optimal configuration of the VPP components (components and size) depends on season, the kind of power plants, and the load profile. As "season" is an external variable that cannot be influenced, and the decision for the VPP components cannot not be changed when undertaken, the selection of the marketing channels allows the greatest chance to maximize the contribution margin.

- The organization of RES in the VPP leads to the generation of secured instead of fluctuating power generation. This secured power could be sold in the futures market at higher and more stable prices compared with the status quo. From this, the average contribution margin of power from RES will increase, and less financial support will be necessary to cover the full costs of RES. By delivering secured power, RES will become competitive against conventional power plants, so that competitive market measures could be used to generate funds (e.g., capacity credits and measurements according to §39j EEG "innovation tender"), which will cause less turbulence in the market compared with the present priority purchase methods that are being used for RES power.

Additionally, in the future, it is recommended to investigate the impact of implementing various RES-based power plant technologies in the different locations with more parameters to be analyzed, such as weather forecast, to the decision support for long term development of VPP in the German power markets.

Author Contributions: D.I.C. developed the main idea of the current study, performed and interpreted the analysis, and wrote the manuscript. K.H. developed the idea of generating secured power from RES and markets it as a power future. M.N. reviewed the paper, providing general supervision and guidance. All authors have read and approved the final manuscript.

Funding: This study was funded by the Federal Ministry of Education and Research in Germany under the program "Forschung an Fachhochschulen" on project called Solar-Biogas-Battery Kombikraftwerk (SoBiBaKo) [13FH006I3].

Conflicts of Interest: The authors declare no conflict of interest.

\section{Nomenclature}

$\begin{array}{ll}\text { Abbreviations } & \\ \text { MWMN } & \text { Monday Winter Middle-Night } \\ \text { MWEM } & \text { Monday Winter Early Morning } \\ \text { MWLM } & \text { Monday Winter Late Morning } \\ \text { MWEA } & \text { Monday Winter Early Afternoon } \\ \text { MWRH } & \text { Monday Winter Rush-Hour } \\ \text { MWOP2 } & \text { Monday Winter Off-Peak 2 } \\ \text { MWBL } & \text { Monday Winter Baseload } \\ \text { MWPL } & \text { Monday Winter Peakload } \\ \text { MWN } & \text { Monday Winter Night } \\ \text { MWOP1 } & \text { Monday Winter Off-Peak 1 } \\ \text { MWB } & \text { Monday Winter Business } \\ \text { MWOP } & \text { Monday Winter Off-Peak } \\ \text { MWM } & \text { Monday Winter Morning } \\ \text { MWHN } & \text { Monday Winter High Noon } \\ \text { MWA } & \text { Monday Winter Afternoon } \\ \text { MWE } & \text { Monday Winter Evening }\end{array}$




\begin{tabular}{|c|c|}
\hline MWSP & Monday Winter Sun Peak \\
\hline MSMN & Monday Summer Middle-Night \\
\hline MSEM & Monday Summer Early Morning \\
\hline MSLM & Monday Summer Late Morning \\
\hline MSEA & Monday Summer Early Afternoon \\
\hline MSRH & Monday Summer Rush-Hour \\
\hline MSOP2 & Monday Summer Off-Peak 2 \\
\hline MSBL & Monday Summer Baseload \\
\hline MSPL & Monday Summer Peakload \\
\hline MSN & Monday Summer Night \\
\hline MSOP1 & Monday Summer Off-Peak 1 \\
\hline MSB & Monday Summer Business \\
\hline MSOP & Monday Summer Off-Peak \\
\hline MSM & Monday Summer Morning \\
\hline MSHN & Monday Summer High Noon \\
\hline MSA & Monday Summer Afternoon \\
\hline MSE & Monday Summer Evening \\
\hline MSSP & Monday Summer Sun Peak \\
\hline WF_SBL & Week Futures Summer Baseload \\
\hline WF_SPL & Week Futures Summer Peakload \\
\hline MWF_WBL & Monday Week Futures Winter Baseload \\
\hline TWF_WBL & Tuesday Week Futures Winter Baseload \\
\hline WWF_WBL & Wednesday Week Futures Winter Baseload \\
\hline ThWF_WBL & Thursday Week Futures Winter Baseload \\
\hline FWF_WBL & Friday Week Futures Winter Baseload \\
\hline SWF_WBL & Saturday Week Futures Winter Baseload \\
\hline SuWF_WBL & Sunday Week Futures Winter Baseload \\
\hline MWF_WPL & Monday Week Futures Winter Peakload \\
\hline TWF_WPL & Tuesday Week Futures Winter Peakload \\
\hline WWF_WPL & Wednesday Week Futures Winter Peakload \\
\hline ThWF_WPL & Thursday Week Futures Winter Peakload \\
\hline FWF_WPL & Friday Week Futures Winter Peakload \\
\hline PL & Peak Load \\
\hline BL & Base Load \\
\hline EA & Early Afternoon \\
\hline B & Business \\
\hline $\mathrm{HN}$ & High-Noon \\
\hline SP & Sun Peak \\
\hline MW & Monday Winter \\
\hline SWMN & Saturday Winter Middle-Night \\
\hline SWEM & Saturday Winter Early Morning \\
\hline SWLM & Saturday Winter Late Morning \\
\hline SWEA & Saturday Winter Early Afternoon \\
\hline SWRH & Saturday Winter Rush-Hour \\
\hline SWOP2 & Saturday Winter Off-Peak 2 \\
\hline SWBL & Saturday Winter Baseload \\
\hline SWPL & Saturday Winter Peakload \\
\hline SWN & Saturday Winter Night \\
\hline SWOP1 & Saturday Winter Off-Peak 1 \\
\hline SWB & Saturday Winter Business \\
\hline SWOP & Saturday Winter Off-Peak \\
\hline SWM & Saturday Winter Morning \\
\hline SWHN & Saturday Winter High Noon \\
\hline SWA & Saturday Winter Afternoon \\
\hline SWE & Saturday Winter Evening \\
\hline
\end{tabular}




\begin{tabular}{|c|c|}
\hline SWSP & Saturday Winter Sun Peak \\
\hline SSMN & Saturday Summer Middle-Night \\
\hline SSEM & Saturday Summer Early Morning \\
\hline SSLM & Saturday Summer Late Morning \\
\hline SSEA & Saturday Summer Early Afternoon \\
\hline SSRH & Saturday Summer Rush-Hour \\
\hline SSOP2 & Saturday Summer Off-Peak 2 \\
\hline SSBL & Saturday Summer Baseload \\
\hline SSPL & Saturday Summer Peakload \\
\hline SSN & Saturday Summer Night \\
\hline SSOP1 & Saturday Summer Off-Peak 1 \\
\hline SSB & Saturday Summer Business \\
\hline SSOP & Saturday Summer Off-Peak \\
\hline SSM & Saturday Summer Morning \\
\hline SSHN & Saturday Summer High Noon \\
\hline SSA & Saturday Summer Afternoon \\
\hline SSE & Saturday Summer Evening \\
\hline SSSP & Saturday Summer Sun Peak \\
\hline WF_WBL & Week Futures Winter Baseload \\
\hline WF_WPL & Week Futures Winter Peakload \\
\hline MWF_SBL & Monday Week Futures Summer Baseload \\
\hline TWF_SBL & Tuesday Week Futures Summer Baseload \\
\hline WWF_SBL & Wednesday Week Futures Summer Baseload \\
\hline ThWF_SBL & Thursday Week Futures Summer Baseload \\
\hline FWF_SBL & Friday Week Futures Summer Baseload \\
\hline SWF_SBL & Saturday Week Futures Summer Baseload \\
\hline SuWF_SBL & Sunday Week Futures Summer Baseload \\
\hline MWF_SPL & Monday Week Futures Summer Peakload \\
\hline TWF_SPL & Tuesday Week Futures Summer Peakload \\
\hline WWF_SPL & Wednesday Week Futures Summer Peakload \\
\hline ThWF_SPL & Thursday Week Futures Summer Peakload \\
\hline FWF_SPL & Friday Week Futures Summer Peakload \\
\hline LM & Late Morning \\
\hline M & Morning \\
\hline $\mathrm{RH}$ & Rush-Hour \\
\hline DA & Day-Ahead market \\
\hline WF & Week Futures market \\
\hline SW & Saturday Winter \\
\hline SS & Saturday Summer \\
\hline \multicolumn{2}{|l|}{ Variables } \\
\hline $\mathrm{BVOL}_{\mathrm{x}}$ & bid volumes of specific market products $x$ \\
\hline $\mathrm{x}$ & the market products (see Table A1) such as base load, peak load, off-peak \\
\hline Ptot $_{1, \mathrm{k}}$ & a total load of the market category $\mathrm{l}$ at time $\mathrm{k}$ \\
\hline Pbase $_{1, k}$ & abase load of the market category $\mathrm{l}$ at time $\mathrm{k}$ \\
\hline $\operatorname{Pavg}_{1, \mathrm{k}}$ & avg. of load data of the market category $\mathrm{l}$ at time $\mathrm{k}$ \\
\hline Paravg $_{1, k}$ & avg. deviation of load data of the market category $\mathrm{l}$ at time $\mathrm{k}$ \\
\hline Ppeakw $_{w}$ & the peak load market product in winter in the Week Futures market \\
\hline Ppeakw $_{\text {su }}$ & the peak load market product in summer in the Week Futures market \\
\hline Paravg $_{5, \mathrm{k}}$ & avg. of load data of Week Futures in winter at time k \\
\hline $\operatorname{Paravg}_{6, \mathrm{k}}$ & avg. deviation of load data of Week Futures in summer at time $\mathrm{k}$ \\
\hline Pres $_{1, \mathrm{k}}$ & the remaining load of the market category $\mathrm{l}$ at time $\mathrm{k}$ \\
\hline $\mathrm{s}_{\mathrm{x}}$ & the number of the signal of the remaining load of the market product $x$ \\
\hline $\mathrm{CM}_{1}$ & the average of contribution margin of the market category $\mathrm{l}$ at time $\mathrm{k}$ \\
\hline Copt $_{1}$ & the average of the optimized cost of the market category $\mathrm{l}$ at time $\mathrm{k}$ \\
\hline $\mathrm{MP}_{1}$ & the average of the market prices of market category $\mathrm{l}$ at time $\mathrm{k}$ \\
\hline 1 & the market categories (Table A5) \\
\hline
\end{tabular}


Constants

$\mathrm{c}_{\mathrm{x}, \mathrm{k}}$

$=1$ if $\mathrm{k}$ is equal to the times where the specific market product $\mathrm{x}$ occurs (see Block Times (h) in Table A2), otherwise 0

$\mathrm{g}_{\mathrm{x}, \mathrm{k}}$ $=1$ is the signal of the remaining load existence in the specific market product $\mathrm{x}$ at time $\mathrm{k}$

$\mathrm{k}$ when the remaining load is bigger than zero, otherwise 0

$\mathrm{k}$ time 1 to $\mathrm{n}$

n $\quad=24$ (for Day-Ahead market) or 168 (for Week Futures market)

\section{Appendix A}

Table A1. All market products of each VPP configuration.

\begin{tabular}{|c|c|c|c|c|c|c|}
\hline Scenario & Market Types & Bid Types & Season & Day(s) & Date(s) & $\mathbf{x}$ \\
\hline 1 & Day-Ahead (SPOT market) & Middle-Night Block & Winter & Monday & 26 January 2015 & 1 \\
\hline 2 & Day-Ahead (SPOT market) & Early Morning Block & Winter & Monday & 26 January 2015 & 2 \\
\hline 3 & Day-Ahead (SPOT market) & Late morning Block & Winter & Monday & 26 January 2015 & 3 \\
\hline 4 & Day-Ahead (SPOT market) & Early Afternoon Block & Winter & Monday & 26 January 2015 & 4 \\
\hline 5 & Day-Ahead (SPOT market) & Rush Hour Block & Winter & Monday & 26 January 2015 & 5 \\
\hline 6 & Day-Ahead (SPOT market) & Off-Peak 2 Block & Winter & Monday & 26 January 2015 & 6 \\
\hline 7 & Day-Ahead (SPOT market) & Baseload Block & Winter & Monday & 26 January 2015 & 7 \\
\hline 8 & Day-Ahead (SPOT market) & Peakload Block & Winter & Monday & 26 January 2015 & 8 \\
\hline 9 & Day-Ahead (SPOT market) & Night Block & Winter & Monday & 26 January 2015 & 9 \\
\hline 10 & Day-Ahead (SPOT market) & Off-Peak 1 Block & Winter & Monday & 26 January 2015 & 10 \\
\hline 11 & Day-Ahead (SPOT market) & Business Block & Winter & Monday & 26 January 2015 & 11 \\
\hline 12 & Day-Ahead (SPOT market) & Off-Peak Block & Winter & Monday & 26 January 2015 & 12 \\
\hline 13 & Day-Ahead (SPOT market) & Morning Block & Winter & Monday & 26 January 2015 & 13 \\
\hline 14 & Day-Ahead (SPOT market) & High Noon Block & Winter & Monday & 26 January 2015 & 14 \\
\hline 15 & Day-Ahead (SPOT market) & Afternoon Block & Winter & Monday & 26 January 2015 & 15 \\
\hline 16 & Day-Ahead (SPOT market) & Evening Block & Winter & Monday & 26 January 2015 & 16 \\
\hline 17 & Day-Ahead (SPOT market) & Sun Peak Block & Winter & Monday & 26 January 2015 & 17 \\
\hline 18 & Day-Ahead (SPOT market) & Middle-Night Block & Winter & Saturday & 31 January 2015 & 18 \\
\hline 19 & Day-Ahead (SPOT market) & Early Morning Block & Winter & Saturday & 31 January 2015 & 19 \\
\hline 20 & Day-Ahead (SPOT market) & Late morning Block & Winter & Saturday & 31 January 2015 & 20 \\
\hline 21 & Day-Ahead (SPOT market) & Early Afternoon Block & Winter & Saturday & 31 January 2015 & 21 \\
\hline 22 & Day-Ahead (SPOT market) & Rush Hour Block & Winter & Saturday & 31 January 2015 & 22 \\
\hline 23 & Day-Ahead (SPOT market) & Off-Peak 2 Block & Winter & Saturday & 31 January 2015 & 23 \\
\hline 24 & Day-Ahead (SPOT market) & Baseload Block & Winter & Saturday & 31 January 2015 & 24 \\
\hline 25 & Day-Ahead (SPOT market) & Peakload Block & Winter & Saturday & 31 January 2015 & 25 \\
\hline 26 & Day-Ahead (SPOT market) & Night Block & Winter & Saturday & 31 January 2015 & 26 \\
\hline 27 & Day-Ahead (SPOT market) & Off-Peak 1 Block & Winter & Saturday & 31 January 2015 & 27 \\
\hline 28 & Day-Ahead (SPOT market) & Business Block & Winter & Saturday & 31 January 2015 & 28 \\
\hline 29 & Day-Ahead (SPOT market) & Off-Peak Block & Winter & Saturday & 31 January 2015 & 29 \\
\hline 30 & Day-Ahead (SPOT market) & Morning Block & Winter & Saturday & 31 January 2015 & 30 \\
\hline 31 & Day-Ahead (SPOT market) & High Noon Block & Winter & Saturday & 31 January 2015 & 31 \\
\hline 32 & Day-Ahead (SPOT market) & Afternoon Block & Winter & Saturday & 31 January 2015 & 32 \\
\hline 33 & Day-Ahead (SPOT market) & Evening Block & Winter & Saturday & 31 January 2015 & 33 \\
\hline 34 & Day-Ahead (SPOT market) & Sun Peak Block & Winter & Saturday & 31 January 2015 & 34 \\
\hline 35 & Day-Ahead (SPOT market) & Middle-Night Block & Summer & Monday & 6 July 2015 & 35 \\
\hline
\end{tabular}


Table A1. Cont.

\begin{tabular}{|c|c|c|c|c|c|c|}
\hline Scenario & Market Types & Bid Types & Season & Day(s) & Date(s) & $x$ \\
\hline 36 & Day-Ahead (SPOT market) & Early Morning Block & Summer & Monday & 6 July 2015 & 36 \\
\hline 37 & Day-Ahead (SPOT market) & Late morning Block & Summer & Monday & 6 July 2015 & 37 \\
\hline 38 & Day-Ahead (SPOT market) & Early Afternoon Block & Summer & Monday & 6 July 2015 & 38 \\
\hline 39 & Day-Ahead (SPOT market) & Rush Hour Block & Summer & Monday & 6 July 2015 & 39 \\
\hline 40 & Day-Ahead (SPOT market) & Off-Peak 2 Block & Summer & Monday & 6 July 2015 & 40 \\
\hline 41 & Day-Ahead (SPOT market) & Baseload Block & Summer & Monday & 6 July 2015 & 41 \\
\hline 42 & Day-Ahead (SPOT market) & Peakload Block & Summer & Monday & 6 July 2015 & 42 \\
\hline 43 & Day-Ahead (SPOT market) & Night Block & Summer & Monday & 6 July 2015 & 43 \\
\hline 44 & Day-Ahead (SPOT market) & Off-Peak 1 Block & Summer & Monday & 6 July 2015 & 44 \\
\hline 45 & Day-Ahead (SPOT market) & Business Block & Summer & Monday & 6 July 2015 & 45 \\
\hline 46 & Day-Ahead (SPOT market) & Off-Peak Block & Summer & Monday & 6 July 2015 & 46 \\
\hline 47 & Day-Ahead (SPOT market) & Morning Block & Summer & Monday & 6 July 2015 & 47 \\
\hline 48 & Day-Ahead (SPOT market) & High Noon Block & Summer & Monday & 6 July 2015 & 48 \\
\hline 49 & Day-Ahead (SPOT market) & Afternoon Block & Summer & Monday & 6 July 2015 & 49 \\
\hline 50 & Day-Ahead (SPOT market) & Evening Block & Summer & Monday & 6 July 2015 & 50 \\
\hline 51 & Day-Ahead (SPOT market) & Sun Peak Block & Summer & Monday & 6 July 2015 & 51 \\
\hline 52 & Day-Ahead (SPOT market) & Middle-Night Block & Summer & Saturday & 11 July 2015 & 52 \\
\hline 53 & Day-Ahead (SPOT market) & Early Morning Block & Summer & Saturday & 11 July 2015 & 53 \\
\hline 54 & Day-Ahead (SPOT market) & Late morning Block & Summer & Saturday & 11 July 2015 & 54 \\
\hline 55 & Day-Ahead (SPOT market) & Early Afternoon Block & Summer & Saturday & 11 July 2015 & 55 \\
\hline 56 & Day-Ahead (SPOT market) & Rush Hour Block & Summer & Saturday & 11 July 2015 & 56 \\
\hline 57 & Day-Ahead (SPOT market) & Off-Peak 2 Block & Summer & Saturday & 11 July 2015 & 57 \\
\hline 58 & Day-Ahead (SPOT market) & Baseload Block & Summer & Saturday & 11 July 2015 & 58 \\
\hline 59 & Day-Ahead (SPOT market) & Peakload Block & Summer & Saturday & 11 July 2015 & 59 \\
\hline 60 & Day-Ahead (SPOT market) & Night Block & Summer & Saturday & 11 July 2015 & 60 \\
\hline 61 & Day-Ahead (SPOT market) & Off-Peak 1 Block & Summer & Saturday & 11 July 2015 & 61 \\
\hline 62 & Day-Ahead (SPOT market) & Business Block & Summer & Saturday & 11 July 2015 & 62 \\
\hline 63 & Day-Ahead (SPOT market) & Off-Peak Block & Summer & Saturday & 11 July 2015 & 63 \\
\hline 64 & Day-Ahead (SPOT market) & Morning Block & Summer & Saturday & 11 July 2015 & 64 \\
\hline 65 & Day-Ahead (SPOT market) & High Noon Block & Summer & Saturday & 11 July 2015 & 65 \\
\hline 66 & Day-Ahead (SPOT market) & Afternoon Block & Summer & Saturday & 11 July 2015 & 66 \\
\hline 67 & Day-Ahead (SPOT market) & Evening Block & Summer & Saturday & 11 July 2015 & 67 \\
\hline 68 & Day-Ahead (SPOT market) & Sun Peak Block & Summer & Saturday & 11 July 2015 & 68 \\
\hline 69 & Week Futures & Baseload & Winter & $\begin{array}{l}\text { Monday to } \\
\text { Sunday }\end{array}$ & $\begin{array}{l}26 \text { January } 2015 \text { to } \\
1 \text { February } 2015\end{array}$ & 69 \\
\hline 70 & Week Futures & Peakload & Winter & $\begin{array}{l}\text { Monday to } \\
\text { Sunday }\end{array}$ & $\begin{array}{l}26 \text { January } 2015 \text { to } \\
1 \text { February } 2015\end{array}$ & 70 \\
\hline 71 & Week Futures & Baseload & Summer & $\begin{array}{l}\text { Monday to } \\
\text { Sunday }\end{array}$ & 6-12 July 2015 & 71 \\
\hline 72 & Week Futures & Peakload & Summer & $\begin{array}{l}\text { Monday to } \\
\text { Sunday }\end{array}$ & 6-12 July 2015 & 72 \\
\hline
\end{tabular}


Table A2. Bid classifications.

\begin{tabular}{cccc}
\hline No. & Market Types & Bid Types & Block Times (h) \\
\hline 1 & Day-Ahead & Middle-Night Block & $01-04$ \\
2 & Day-Ahead & Early Morning Block & $05-08$ \\
3 & Day-Ahead & Late morning Block & $09-12$ \\
4 & Day-Ahead & Early Afternoon Block & $13-16$ \\
5 & Day-Ahead & Rush Hour Block & $17-20$ \\
6 & Day-Ahead & Off-Peak 2 Block & $21-24$ \\
7 & Day-Ahead & Baseload Block & $01-24$ \\
8 & Day-Ahead & Peakload Block & $08-20$ \\
9 & Day-Ahead & Night Block & $01-06$ \\
10 & Day-Ahead & Off-Peak 1 Block & $01-08$ \\
11 & Day-Ahead & Business Block & $09-16$ \\
12 & Day-Ahead & Off-Peak Block & $01-08 \& 21-24$ \\
13 & Day-Ahead & Morning Block & $07-10$ \\
14 & Day-Ahead & High Noon Block & $11-14$ \\
15 & Day-Ahead & Afternoon Block & $15-18$ \\
16 & Day-Ahead & Evening Block & $19-24$ \\
17 & Day-Ahead & Sun Peak Block & $11-16$ \\
18 & Week Futures & Peakload Block & $08-20$ (Monday-Friday) \\
19 & Week Futures & Baseload Block & $01-24$ (Monday-Sunday) \\
\hline
\end{tabular}

Table A3. Bid prices [45].

\begin{tabular}{cccccccc}
\hline Bid Types & $\begin{array}{c}\text { Prices } \\
(\boldsymbol{\epsilon} / \mathbf{M W h})\end{array}$ & Bid Types & $\begin{array}{c}\text { Prices } \\
(\boldsymbol{\epsilon} / \mathbf{M W h})\end{array}$ & Bid Types & $\begin{array}{c}\text { Prices } \\
(\boldsymbol{\epsilon} / \mathbf{M W h})\end{array}$ & Bid Types & $\begin{array}{c}\text { Prices } \\
(\boldsymbol{\epsilon} / \mathbf{M W h})\end{array}$ \\
\hline MWMN & 26 & SWMN & 26.64 & MSMN & 22.52 & SSMN & 35.23 \\
MWEM & 37.5 & SWEM & 25.4 & MSEM & 28.12 & SSEM & 29.84 \\
MWLM & 48.3 & SWLM & 29.14 & MSLM & 37.16 & SSLM & 30.43 \\
MWEA & 44.28 & SWEA & 28.5 & MSEA & 27.52 & SSEA & 28.26 \\
MWRH & 41.42 & SWRH & 40.39 & MSRH & 47.15 & SSRH & 33.65 \\
MWOP2 & 27.51 & SWOP2 & 28.81 & MSOP2 & 59.86 & SSOP2 & 41.88 \\
MWBL & 37.5 & SWBL & 29.81 & MSBL & 33.21 & SSBL & 37.05 \\
MWPL & 44.67 & SWPL & 32.68 & MSPL & 30.78 & SSPL & 37.28 \\
MWN & 26.15 & SWN & 26.11 & MSN & 21.61 & SSN & 33.06 \\
MWOP1 & 31.75 & SWOP1 & 26.02 & MSOP1 & 25.32 & SSOP1 & 32.54 \\
MWB & 46.29 & SWB & 28.82 & MSB & 32.34 & SSB & 29.34 \\
MWOP & 30.34 & SWOP & 26.95 & MSOP & 36.83 & SSOP & 35.65 \\
MWM & 49.4 & SWM & 27.35 & MSM & 38.76 & SSM & 31.28 \\
MWHN & 46.23 & SWHN & 28.84 & MSHN & 30.58 & SSHN & 29.25 \\
MWA & 42.4 & SWA & 33.12 & MSA & 31.84 & SSA & 28.11 \\
MWE & 31.84 & SWE & 33.62 & MSE & 59.16 & SSE & 40.7 \\
MWSP & 44.97 & SWSP & 28.78 & MSSP & 29.43 & SSSP & 28.59 \\
MWF_WBL & 37.50 & MWF_WPL & 44.67 & MWF_SBL & 37.05 & MWF_SPL & 37.28 \\
TWF_WBL & 32.94 & TWF_WPL & 40.21 & TWF_SBL & 49.02 & TWF_SPL & 53.83 \\
WWF_WBL & 28.18 & WWF_WPL & 30.19 & WWF_SBL & 29.57 & WWF_SPL & 27.98 \\
ThWF_WBL & 26.24 & ThWF_WPL & 32.7 & ThWF_SBL & 28.7 & ThWF_SPL & 28.5 \\
FWF_WBL & 38.24 & FWF_WPL & 46.04 & FWF_SBL & 32.14 & FWF_SPL & 31.62 \\
SWF_WBL & 29.81 & & SWF_SBL & 33.21 & & \\
SuWF_WBL & 29.23 & & & SuWF_SBL & 27.9 & & \\
\hline
\end{tabular}


Table A4. Total volume each bid types.

\begin{tabular}{|c|c|c|c|c|c|c|c|}
\hline Bid Types & $\begin{array}{c}\text { Total } \\
\text { Volumes } \\
\text { (MWh) }\end{array}$ & Bid Types & $\begin{array}{c}\text { Total } \\
\text { Volumes } \\
(\mathrm{MWh})\end{array}$ & Bid Types & $\begin{array}{c}\text { Total } \\
\text { Volumes } \\
\text { (MWh) }\end{array}$ & Bid Types & $\begin{array}{c}\text { Total } \\
\text { Volumes } \\
\text { (MWh) }\end{array}$ \\
\hline MWMN & 44.09 & SWMN & 56.83 & MSMN & 0 & SSMN & 0 \\
\hline MWEM & 0 & SWEM & 0 & MSEM & 0 & SSEM & 14.38 \\
\hline MWLM & 29.65 & SWLM & 43.62 & MSLM & 86.47 & SSLM & 49.62 \\
\hline MWEA & 78.79 & SWEA & 131.34 & MSEA & 95.49 & SSEA & 63.16 \\
\hline MWRH & 95.95 & SWRH & 136.58 & MSRH & 82.63 & SSRH & 57.32 \\
\hline MWOP2 & 89.29 & SWOP2 & 146.11 & MSOP2 & 35.67 & SSOP2 & 24.60 \\
\hline MWBL & 792.41 & SWBL & 1255.63 & MSBL & 1259.63 & SSBL & 766.42 \\
\hline MWPL & 227.47 & SWPL & 347.67 & MSPL & 277.05 & SSPL & 189.36 \\
\hline MWN & 66.14 & SWN & 85.24 & MSN & 0 & SSN & 0 \\
\hline MWOP1 & 88.18 & SWOP1 & 113.65 & MSOP1 & 32.62 & SSOP1 & 28.76 \\
\hline MWB & 124.82 & SWB & 204.20 & MSB & 181.96 & SSB & 112.77 \\
\hline MWOP & 200.08 & SWOP & 304.41 & MSOP & 92.50 & SSOP & 66.13 \\
\hline MWM & 0 & SWM & 0 & MSM & 41.87 & SSM & 30.35 \\
\hline MWHN & 49.99 & SWHN & 85.26 & MSHN & 105.20 & SSHN & 60.88 \\
\hline MWA & 96.33 & SWA & 141.90 & MSA & 90.38 & SSA & 63.45 \\
\hline MWE & 132.53 & SWE & 208.68 & MSE & 74.46 & SSE & 54.06 \\
\hline MWSP & 93.61 & SWSP & 153.15 & MSSP & 148.25 & SSSP & 93.61 \\
\hline WF_WBL & 6379.94 & & & & & & \\
\hline WF_WPL & 2129.39 & & & & & & \\
\hline WF_SBL & 4817.15 & & & & & & \\
\hline WF_SPL & 1398.66 & & & & & & \\
\hline
\end{tabular}

Table A5. Market categories.

\begin{tabular}{ccc}
\hline No. & Market Categories & $\mathbf{1}$ \\
\hline 1 & Day-Ahead Monday Winter & 1 \\
2 & Day-Ahead Monday Summer & 2 \\
3 & Day-Ahead Saturday Winter & 3 \\
4 & Day-Ahead Saturday Summer & 4 \\
5 & Week Futures Winter & 5 \\
6 & Week Futures Summer & 6 \\
\hline
\end{tabular}

\section{References}

1. The Federal Ministry for Economic Affairs and Energy. Renewable Energy Sources in Figures. National and International Development. 2016. Available online: https:/ /www.bmwi.de/Redaktion/EN/Publikationen/ renewable-energy-sources-in-figures-2016.pdf?_blob=publicationFile\&v=5 (accessed on 18 March 2018).

2. Bundesverband der Energie-Und Wasserwirtschaft e.V. Foliensatz zur BDEW—Energie—Info Erneuerbare Energien und das EEG: Zahlen, Fakten, Grafiken (2017). Anlagen, Installierte Leistung, Stromerzeugung, Marktintegration der Erneuerbaren Energien, EEG-Auszahlungen und Regionale Verteilung der EEG-Anlagen. Available online: https://www.google.com/url?sa=t\&rct=j\&q=\&esrc=s\&source=web\& $\mathrm{cd}=1 \& \mathrm{cad}=$ rja\&uact=8\&ved=0ahUKEwjglu7L1pncAhXBKJoKHb_3AMAQFggvMAA\&url=https $\% 3 \mathrm{~A} \%$ 2F\%2Fwww.bdew.de\%2Fmedia\%2Fdocuments\%2FAwh_20170710_Erneuerbare-Energien-EEG_2017.pdf\& usg=AOvVaw110BDCzB8uWNJv4GOyNbhO (accessed on 18 March 2018).

3. Ziesing, H. Energy Consumption. in Germany in 2015. Available online: https: / / www.google.com/url?sa=t\&rct=j\&q=\&esrc=s\&source=web\&cd=1\&cad=rja\&uact=8\&ved= 0ahUKEwiEst2H2ZncAhXhB5oKHR31An4QFggyMAA\&url=https\%3A\%2F\%2Fag-energiebilanzen. de\%2Findex.php\%3Farticle_id\%3D29\%26fileName\%3Dageb_jahresbericht2015_20160418_engl.pdf\&usg= AOvVaw3A6wlJImHFPjoz0HtskctZ (accessed on 5 May 2018). 
4. Bundesnetzagentur für Elektrizität, Gas, Telekommunikation, Post und Eisenbahnen. Monitoring Report 2015. Available online: https://www.bundesnetzagentur.de/SharedDocs/Downloads/EN/ BNetzA/PressSection/ReportsPublications/2015/Monitoring_Report_2015_Korr.pdf;jsessionid= 3592D4D55ED7B30AC9C561D0CA5788B4?_blob=publicationFile\&v=4 (accessed on 22 February 2018).

5. Wassermann, S.; Reeg, M.; Nienhaus, K. Current challenges of Germany's energy transition project and competing strategies of challengers and incumbents: The case of direct marketing of electricity from renewable energy sources. Energy Policy 2015, 76, 66-75. [CrossRef]

6. Pollitt, M.G.; Anaya, K.L. Can current electricity markets cope with high shares of renewables? A comparison of approaches in Germany, the UK and the State of New York. Energy J. 2016, 37, 69-89. [CrossRef]

7. Kopp, O.; Eßer-Frey, A.; Engelhorn, T. Können sich erneuerbare Energien langfristig auf wettbewerblich organisierten Strommärkten finanzieren? Z. Energiewirtschaft 2012, 36, 243-255. [CrossRef]

8. Dotzauer, M.; Naumann, K.; Billig, E.; Thrän, D. Demand for the flexible provision of bioenergy carriers: An overview of the different energy sectors in Germany. In Smart Bioenergy; Springer: Heidelberg, Germany, 2015; pp. 11-31.

9. Houwing, M.; Papaefthymiou, G.; Heijnen, P.W.; Ilic, M.D. Balancing wind power with virtual power plants of micro-CHPs. In Proceedings of the 2009 IEEE Bucharest Power Tech, Bucharest, Romania, 28 June-2 July 2009; pp. 1-6.

10. Koraki, D.; Strunz, K. Wind and solar power integration in electricity markets and distribution networks through service-centric virtual power plants. IEEE Trans. Power Syst. 2017, 33, 473-485. [CrossRef]

11. Garcia, H.E.; Mohanty, A.; Lin, W.-C.; Cherry, R.S. Dynamic analysis of hybrid energy systems under flexible operation and variable renewable generation—Part I: Dynamic performance analysis. Energy 2013, 52, 1-16. [CrossRef]

12. Heide, D.; Greiner, M.; von Bremen, L.; Hoffmann, C. Reduced storage and balancing needs in a fully renewable european power system with excess wind and solar power generation. Renew. Energy 2011, 36, 2515-2523. [CrossRef]

13. Gils, H.C. Balancing of Intermittent Renewable Power Generation by Demand Response and Thermal Energy Storage. Ph.D. Thesis, University of Stuttgart, Stuttgart, Germany, December 2015.

14. Hochloff, P.; Braun, M. Optimizing biogas plants with excess power unit and storage capacity in electricity and control reserve markets. Biomass Bioenergy 2013, 65, 125-135. [CrossRef]

15. Petersen, M.K.; Hansen, L.H.; Bendtsen, J.; Stoustrup, J. Market integration of virtual power plants. In Proceedings of the 52nd IEEE Conference on Decision and Control, Florence, Italy, 10-13 December 2013; pp. 2319-2325.

16. Mashhour, E.; Moghaddas-Tafreshi, S.M. Bidding strategy of virtual power plant for participating in energy and spinning reserve markets-Part II: Numerical analysis. IEEE Trans. Power Syst. 2010, 26, 957-964. [CrossRef]

17. Zamani, A.G.; Zakariazadeh, A.; Jadid, S. Day-ahead resource scheduling of a renewable energy based virtual power plant. Appl. Energy 2016, 169, 324-340. [CrossRef]

18. Lukovic, S.; Kaitovic, I.; Mura, M.; Bondi, U. Virtual power plant as a bridge between distributed energy resources and smart grid. In Proceedings of the 2010 43rd Hawaii International Conference on System Sciences, Honolulu, HI, USA, 5-8 January 2010; pp. 1-8.

19. Nikonowicz, L.; Milewski, J. Virtual power plants-general review: Structure, application and optimization. J. Power Technol. 2012, 92, 135-149.

20. Däneka, C.; König, A.; Mayer, C.; Rohjan, S.; Bischoff, S.; Breuer, A.; Drzisga, T.; Hecht, J.; Holtermann, M.; Luhmann, T.; et al. Future Energy Grid: Migration to the Internet of Energy. Acatech Study. Available online: https://www.google.com/url?sa=t\&rct=j\&q=\&esrc=s\&source=web\&cd=2\&cad=rja\& uact=8\&ved=0ahUKEwjSvI6H9pncAhUGyKYKHYDnD1wQFgg0MAE\&url=http \%3A\%2F\%2Fwww.

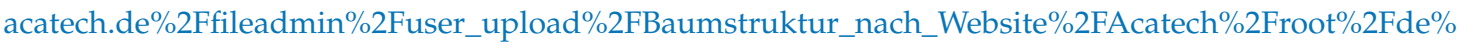
2FPublikationen\%2FEnglisch\%2FEIT-ICT-Labs_acatech-Study_Future_Energy_Grid_final.pdf\&usg= AOvVaw18kW8X6pcrEhM3g8Qnausr (accessed on 2 May 2018).

21. Sexauer, S. Internet of Energy ICT for Energy Markets of the Future: The Energy Industry on the Way to the Internet Age. Available online: https:/ / www.iese.fraunhofer.de/content/dam/iese/en/mediacenter/ documents/BDI_initiative_IoE_us-IdE-Broschuere_tcm27-45653.pdf (accessed on 3 February 2018). 
22. Loßner, M.; Böttger, D.; Bruckner, T. Economic assessment of virtual power plants in the German energy market-A scenario-based and model-supported analysis. Energy Econ. 2017, 62, 125-138. [CrossRef]

23. Sowa, T.; Krengel, S.; Koopmann, S.; Nowak, J. Multi-criteria operation strategies of power-to-heat-systems in virtual power plants with a high penetration of renewable energies. Energy Proc. 2014, 46, 237-245. [CrossRef]

24. Plancke, G.; De Vos, K.; Belmans, R.; Delnooz, A. Virtual power plants: Definition, applications and barriers to the implementation in the distribution system. In Proceedings of the 201512 th International Conference on the European Energy Market (EEM), Lisbon, Portugal, 19-22 May 2015; pp. 1-5.

25. Pandžić, H.; Morales, J.M.; Conejo, A.J.; Kuzle, I. Offering model for a virtual power plant based on stochastic programming. Appl. Energy 2013, 105, 282-292. [CrossRef]

26. Arslan, O.; Karasan, O.E. Cost and emission impacts of virtual power plant formation in plug-in hybrid electric vehicle penetrated networks. Energy 2013, 60, 116-124. [CrossRef]

27. Kok, K. The PowerMatcher: Smart Coordination for the Smart Electricity Grid. Ph.D. Thesis, Vrije Universiteit, Amsterdam, The Netherlands, 2013.

28. Chen, Z. Virtual Power Plant Simulation and Control Scheme Design. Master's Thesis, KTH Royal Institute of Technology, Stockholm, Sweden, 2012.

29. Bahrami, S.; Amini, H.M.; Shafie-khah, M.; Catalao, J.P.S. A decentralized renewable generation management and demand response in power distribution networks. IEEE Trans. Sustain. Energy 2018. [CrossRef]

30. Corera, J.; Maire, J. Flexible Electricity Networks to Integrate the Expected Energy Evolution. Available online: https:/ / www.google.com/url?sa=t\&rct=j\&q=\&esrc=s\&source=web\&cd=2\& cad=rja\&uact=8\&ved=0ahUKEwiE44fe-pncAhWQxKYKHT34DuUQFgg7MAE\&url=http \%3A\%2F\% 2Ffenix.iee.fraunhofer.de\%2Fdocs\%2Fatt2x\%2F2009_Fenix_Book_FINAL_for_selfprinting.pdf\&usg= AOvVaw3CARJB81POiwNDgRmolEiQ (accessed on 13 May 2018).

31. Ghadivel, S.; Li, L.; Aghaei, J.; Yu, T.; Zhu, J. A review on the virtual power plant: Components and operation systems. In Proceedings of the 2016 IEEE International Conference on Power System Technology (POWERCON), Wollongong, NSW, Australia, 28 September-1 October 2018; pp. 1-6. [CrossRef]

32. Siemens, A.G. Virtual Power Plants by Siemens. DEMS-Decentralized Energy Management System. Available online: https://www.google.com/url?sa=t\&rct=j\&q=\&esrc=s\&source=web\&cd=1\&cad= rja\&uact=8\&ved=0ahUKEwiDjYvw-5ncAhXhNpoKHZGoCqUQFgg0MAA\&url=https\%3A\%2F\%2Fw3. siemens.com\%2Fsmartgrid\%2Fglobal\%2Fen\%2Fresource-center\%2Femeterresources\%2FDocuments $\%$ 2FDEMS_DataSheet.pdf\&usg=AOvVaw0k331hVRZiolcJCqkBezOV (accessed on 2 February 2017).

33. Lombardi, P.; Powalko, M.; Rudion, K. Optimal operation of a virtual power plant. In Proceedings of the Power \& Energy Society General Meeting, Calgary, AB, Canada, 26-30 July 2009; pp. 1-6.

34. Saboori, H.; Mohammadi, M.; Taghe, R. Virtual power plant (VPP), definition, concept, components and types. In Proceedings of the 2011 Asia-Pacific Power and Energy Engineering Conference, Wuhan, China, 25-28 March 2011; pp. 1-4.

35. Decker, M. Analysis and Design of an SOA for Virtual Power Plants. Master's Thesis, Technical University of Denmark, Kongens Lyngby, Denmark, 2008.

36. EI Bakari, K.; Myrzik, J.M.; Kling, W.L. Prospects of a virtual power plant to control a cluster of distributed generation and renewable energy sources. In Proceedings of the 2009 44th International Universities Power Engineering Conference (UPEC), Glasgow, UK, 1-4 September 2009; pp. 1-5.

37. Vandoorn, T.L.; Zwaenepoel, B.; De Kooning, J.D.M.; Meersman, B.; Vandevelde, L. Smart microgrids and virtual power plants in a hierarchical control structure. In Proceedings of the 2011 2nd IEEE PES International Conference and Exhibition on Innovative Smart Grid Technologies, Manchester, UK, 5-7 December 2011; pp. 1-7.

38. Olejnczak, T. Distributed Generation and Virtual Power Plants: Barriers and Solutions. Master's Thesis, Utrecht University, Utrecht, The Netherlands, 2011.

39. Nezamabadi, P.; Gharehpetian, G. Electrical energy management of virtual power plants in distribution networks with renewable energy resources and energy storage systems. In Proceedings of the 16th Electrical Power Distribution Confernece, Bandar Abbas, Iran, 19-20 April 2011; pp. 1-5.

40. El Bakari, K.; Kling, W.L. Smart grids combination of 'virtual power plant'-concept and 'smart network'-design. In Proceedings of the Young Researchers Symposium, Leuven, Belgium, 29-30 March 2010; pp. 1-5. 
41. Ganagin, W.; Loewen, A.; Hahn, H.; Nelles, M. Flexible Biogaserzeugung durch technische und prozessbiologische Verfahrensanpassung. In Proceedings of the 8. Rostocker Bioenergieforum, Rostock, Germany, 19-20 June 2014; pp. 79-93.

42. Candra, D.I.; Hartmann, K.; Nelles, M. Conceptual and practical implementation of integrated flexible biogas-intermittent re-battery storage for reliable and secure power supply to meet actual load demand at optimal cost. In Proceedings of the 25th European Biomass Conference and Exhibition, Stockholm, Sweden, 12-15 June 2017; pp. 1863-1872.

43. Conkling, R.L. Energy Pricing: Economics and Principles. Energy Systems; Springer: Berlin/Heidelberg, Germany, 2011; pp. 301-324. ISBN 978-3-642-15491-1.

44. Konstantin, P. Praxisbuch Energiewirtschaft: Energieumwandlung, -Transport und -Beschaffung im Liberalisierten Markt; VDI; Springer: Berlin/Heidelberg, Germany, 2013; ISBN 978-3-662-49822-4.

45. EPEXSPOT. Available online: http://www.epexspot.com/en/market-data/dayaheadauction (accessed on 2 February 2017).

46. Zoerner, T. Lastprofil/Lastganganalyse-Synthetische Verteilung der Verbrauchsmengen. Available online: https://blog.stromhaltig.de/2013/06/lastprofillastganganalyse-synthetische-verteilung-derverbrauchsmengen (accessed on 22 February 2018).

47. Candra, D.I.; Hartmann, K.; Nelles, M. Development of a virtual power plant to control distributed energy resources for future smart grid. In Proceedings of the NEIS 2017 Conference on Sustainable Energy Supply and Energy Storage Systems, Hamburg, Germany, 21-22 September 2017; p. 229.

48. Bhattacharyya, S.C. Energy Economics. Concepts, Issues, Markets and Governance; Springer: London, UK, 2011.

49. Pandžić, H.; Kuzle, I.; Capuder, T. Virtual power plant mid-term dispatch optimization. Appl. Energy 2012, 101, 134-141. [CrossRef]

50. Condesso, J.M.A. Electricity Market Simulator for Management of Virtual Power Plants. Master's Thesis, Tecnico Lisboa, Lisboa, Portugal, 2015.

51. Rahimiyan, M.; Baringo, L. Strategic bidding for a virtual power plant in the day-ahead and real-time markets: A price-taker robust optimization approach. IEEE Trans. Power Syst. 2016, 31, 2676-2687. [CrossRef]

52. Shabanzadeh, M.; Sheikh-El-Eslami, M.-K.; Haghifam, M.-R. The design of a risk-hedging tool for virtual power plants via robust optimization approach. Appl. Energy 2015, 155, 766-777. [CrossRef]

53. Aschmann, V.; Effenberger, M. Biogas-BHKW in der Praxis: Wirkungsgrade und Emissionen. p. 15. Available online: https: / www.maiskomitee.de/web/download.aspx?path=/web/upload/documents / kh_docs / versions/a47b8245-5950-4d7b-9f0a-2e66a67c22ba.pdf (accessed on 12 June 2016).

54. ASUE. BHKW Kenndaten 2011 Module Anbieter Kosten. Available online: https://asue.de/sites / default/ files/asue/themen/blockheizkraftwerke/2011/broschueren/05_07_11_asue-bhkw-kenndaten-0311.pdf (accessed on 2 May 2015).

55. Bofinger, S.; Braun, M.; Costa Gomez, C.; Daniel-Gromke, J.; Gerhardt, N. Kurzfassung Die Rolle des Stroms aus Biogasanlagen in zukünftigen Energieversorgungsstrukturen. Available online: http:/ / publica. fraunhofer.de/eprints/urn_nbn_de_0011-n-4066991.pdf (accessed on 2 May 2015).

56. Schmid, J.; Rohrig, K.; Braun, M.; Gerhard, N.; Hochloff, P.; Hoffstede, U.; Lesch, K.; Schögl, F.; Speckmann, M.; Ritzau, M.; et al. Wissenschaftliche Begleitung bei der fachlichen Ausarbeitung eines Kombikraftwerksbonus gemäß der Verordnungsermächtigung §64 EEG2009. Available online: https:/ / www.erneuerbare-energien.de/EE/Redaktion/DE/Downloads/Berichte/ausarbeitungkombikraftwerksbonus.pdf?_blob=publicationFile\&v=3 (accessed on 2 May 2015).

57. Dachs, G.; Rehm, W. Der Eigenstromverbrauch von Biogasanlagen und Potenziale zu dessen Reduzierung, Solarenergieförderverein. p. 25. Available online: https://www.sev-bayern.de/content/bio-eigen.pdf (accessed on 2 May 2015).

58. BMWI. Durchschnittlicher Strompreis für ein Industrieunternehmen in Cent/kWh. Available online: https:/ / www.bmwi.de/Redaktion/DE/Downloads/I/Infografiken/durchschnittlicher-strompreisindustrieunternehmen.pdf?_blob=publicationFile\&v=6 (accessed on 25 December 2016). 
59. Müsgens, F. EWI-Workingpaper. vol. 04.3. Market Power in the German Wholesale Electricity Market. Available online: http:/ / www.ewi.uni-koeln.de/fileadmin/user_upload/Publikationen/Working_Paper/ EWI_WP_04-03_German-Wholesale-Electricity-Market.pdf (accessed on 15 May 2017).

60. Richter, J.; Adigbli, P. Position Paper of the European Energy Exchange and EPEX SPOT: Further Development of the Renewable Support Schemes in Germany. Available online: https:/ / www.epexspot.com/document/26378/Further\%20Development\%20of\%20the\%20Renewable\% 20Support\%20Schemes\%20in\%20Germany (accessed on 12 January 2018).

2018 by the authors. Licensee MDPI, Basel, Switzerland. This article is an open access article distributed under the terms and conditions of the Creative Commons Attribution (CC BY) license (http:/ / creativecommons.org/licenses/by/4.0/). 